
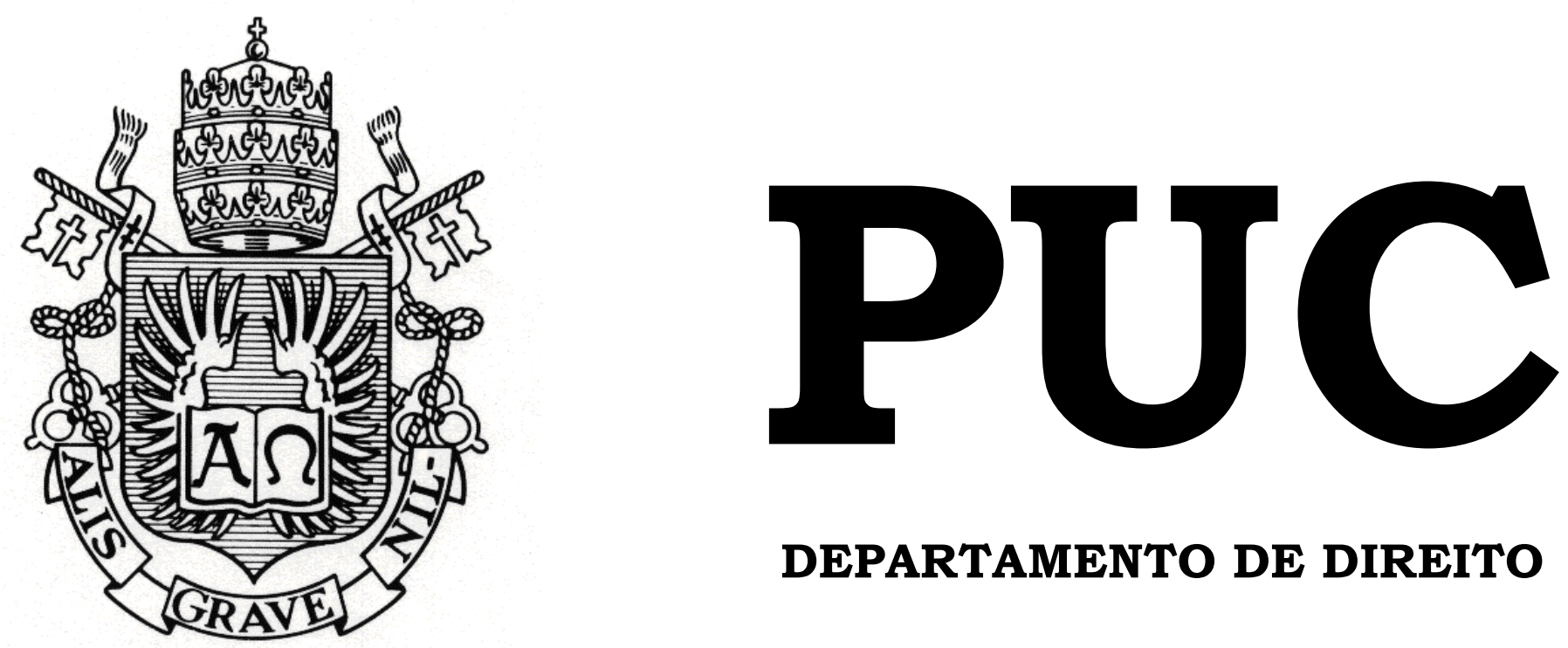

DEPARTAMENTO DE DIREITO

\title{
POLÍTICA DE PACIFICAÇÃO DE FAVELAS (UPP'S): FUNDAMENTOS JURÍDICO-POLÍTICOS E SUAS CRÍTICAS
}

por

GUILHERME SOLEDADE SILVA

ORIENTADOR(A): Adriano Pilatti

2016.2

PONTIFÍCIA UNIVERSIDADE CATÓLICA DO RIO DE JANEIRO

RUA MARQUÊS DE SÃO VICENTE, 225 - CEP 22453-900

RIO DE JANEIRO - BRASIL 


\title{
POLÍTICA DE PACIFICAÇÃO DE FAVELAS (UPP'S): FUNDAMENTOS JURÍDICO-POLÍTICOS E SUAS CRÍTICAS
}

\author{
por \\ GUILHERME SOLEDADE SILVA
}

Monografia apresentada ao

Departamento de Direito da Pontificia Universidade Católica do Rio de Janeiro (PUC-Rio) para a obtenção do Título de Bacharel em Direito.

Orientador (a): Adriano Pilatti

Co-Orientador(a): Alexandre Mendes 


\section{Dedicatória}

Ao primo Rafael (in memoriam). 


\section{Agradecimentos}

Aos meus orientadores, Adriano e Alexandre, pelo suporte e confiança na produção deste trabalho e a liberdade de ideias e construções.

Aos meus pais por todo amor e carinho e que sempre me incentivaram a estudar e dedicaram seus esforços e recursos.

Aos meus irmãos, Thayane e Felipe, pelo apoio incondicional, em todos os sentidos, de todas as minhas decisões e de serem exemplos de vida e superação das metas que você se propor a vencer.

Aos professores Adriano Pilatti, Alexandre Mendes, Andre Perecmanis, Thula Pires, Heloisa Carpena, Letícia Martel e Thiago Varela, que além da excelência no transmitir de seus saberes, agregaram novos valores à minha formação profissional e pessoal, aumentando a minha capacidade de ver e entender o mundo, além de destacar a importância do direito na sociedade. 


\section{Resumo}

A UPP, unidade de polícia pacificadora, é uma política pública adotada pelo Governo do Estado do Rio de Janeiro desde 2008, que visa combater a violência e o tráfico de drogas nas favelas, através da ocupação destes territórios. Segundo consta no artigo primeiro do decreto estadual 42.787 do Rio de Janeiro, as UPP's foram “criadas para a execução de ações especiais concernentes à pacificação e à preservação da ordem pública", visando contemplar áreas "compreendidas por comunidades pobres, com baixa institucionalidade e alto grau de informalidade, em que a instalação oportunista de grupos criminosos ostensivamente armados afronta o Estado Democrático de Direito" com os objetivos de "a. consolidar o controle estatal sobre comunidades sob forte influência de criminalidade ostensivamente armada; b. devolver à população local a paz e a tranquilidade públicas necessárias ao exercício da cidadania plena que garanta o desenvolvimento tanto social quanto econômico." Nesse contexto, este trabalho se propõe a investigar as definições teórico-jurídicas que fundamentam, justificam e estabelecem diretrizes e objetivos das Unidades de Polícia Pacificadora (UPP’s). Identificando os pontos de divergência entre os discursos teóricos, políticos, jurídicos e as intervenções públicas dos moradores de favelas, dos movimentos sociais, seguida de uma leitura histórica da formação das favelas -baseada na obra de Rafael Soares Gonçalves-, além de problematizar o discurso sobre a ausência do estado e a consequente informalidade resultante desta ausência. Por fim, busca-se compreender como se desenvolveu a proposta de pacificação e regularização dos serviços, numa análise de mercado, e em que medida ela está atrelada ao fato da cidade sediar os "megaeventos".

Palavras-chave: UPP, moradia, favela, integração, estado, informalidade 


\section{Sumário}

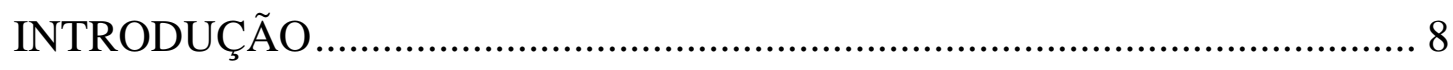

CAPÍTULO I

A Suposta Ausência do Estado nas Favelas ............................................... 11

CAPÍTULO II

A omissão do Estado gera informalidade nas favelas ................................. 20

CAPÍTULO III

A regularização da informalidade como nova fronteira do mercado ............... 26

3.1 - A formação do conceito de UPP Social e a chegada de serviços ........ 31

3.2 - A atuação da Light em favelas com UPP (Caso Chapéu-Mangueira) 35

3.3 - Especulação imobiliária e os desafios da Estradinha e Vila

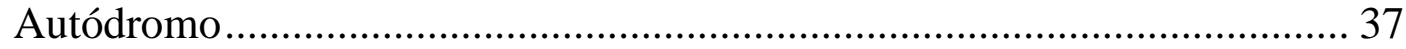

CAPÍTULO IV

A Utopia da nova classe média ......................................................... 44

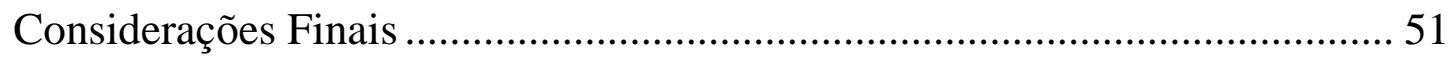

Referências bibliográficas .......................................................... 53 


\section{Lista de siglas e abreviações}

AEIS - Área de Especial Interesse Social

APA - Área de Proteção Ambiental

ART. - Artigo

CREA - Conselho Regional de Engenharia e Arquitetura

DUDH - Declaração Universal dos Direitos Humanos

GEO-RIO - Instituto de Geotécnica do Município do Rio de Janeiro

IPP - Instituto Municipal de Urbanismo Pereira Passos

NUTH - Núcleo de Terras e Habitação da Defensoria Pública

SMH - Secretaria Municipal de Habitação

SMU - Secretaria Municipal de Urbanismo 


\section{INTRODUÇÃO}

As UPP's (Unidades de Polícia Pacificadora) foram regulamentadas pelo Decreto Estadual n 42.787 de 2011, do Estado do Rio de Janeiro. Conforme consta em seu artigo primeiro,elas foram "criadas para a execução de ações especiais concernentes à pacificação e à preservação da ordem pública", visando contemplar áreas "compreendidas por comunidades pobres, com baixa institucionalidade e alto grau de informalidade, em que a instalação oportunista de grupos criminosos ostensivamente armados afronta o Estado Democrático de Direito", com os objetivos de "a. consolidar o controle estatal sobre comunidades sob forte influência de criminalidade ostensivamente armada; $b$. devolver à população local a paz e a tranquilidade públicas necessárias ao exercício da cidadania plena que garanta o desenvolvimento tanto social quanto econômico".

O decreto supracitado, como texto legislativo, faz parte de um conjunto heterogêneo de documentos púbicos, governamentais, teóricos e doutrinários que fundamentam a importância da politica de pacificação a partir de duas premissas básicas: (i) as UPP's buscam retomar ou consolidar a presença do Estado na favelas, logo, a consequência lógica dessa premissa seria a necessidade de uma ocupação permanente das favelas, de forma a restabelecer nessas "comunidades apartadas da cidade" o "Estado Democrático de Direito"1 (dimensão político-jurídica); (ii) a ausência do Estado ou do controle estatal é

\footnotetext{
${ }^{1}$ Ambos os termos foram utilizados por José Mariano Beltrame, Secretário de Segunça Pública do Rio de Janeiro, para definir os resultados iniciais das "experiências de pacificação" em livro denominado: BELTRAME, S. Todo dia é segunda-feira. Rio de Janeiro: Sextante. 2014. Na mesma referência podemos encontrar a premissa da retomada pelo Estado a partir de uma dimensão territorial: "Por décadas, a lógica era colocar a polícia para prender criminosos e reprimir a venda de drogas. Essa estratégia ignorava o ambiente e as relações locais. $\mathrm{O}$ tráfico, por coerção, operava na mente das pessoas havia muito tempo. Ele mandava no território e o crime era a consequência e não mais a motivação deste controle. Com base nessa lógica, tínhamos de desalojar o traficante do lugar simbólico de 'chefe do morro'. Em vez de prometer atacar o crime, prender pessoas e acabar com as drogas, nosso compromisso era retomar o território." (grifo nosso)
} 
diretamente responsável pelos alto grau de informalidade e baixo grau de institucionalidade vivenciados nesses territórios, devendo a UPP constituir uma oportunidade para a regularização e legalização de uma série de atividades destinadas ao desenvolvimento econômico-social das favelas (dimensão econômica e social).

Com base nas premissas acima indicadas, pretende-se analisar as UPP's - não sob a perspectiva específica da segurança pública - mas como uma política mais ampla que veicula uma proposta de "integração da favela à cidade". Essa proposta é divulgada por definições teórico-jurídicas que fundamentam, justificam e estabelecem diretrizes e objetivos das Unidades de Polícia Pacificadora (UPP’s), e também por discursos produzidos por pesquisadores que exercem cargos públicos estratégicos, artigos acadêmicos, documentos governamentais e publicações nos meios de comunicação.

Assim, o presente trabalho se propõe a compreender a política de implementação das unidades de polícia pacificadora dentro da perspectiva da teoria de uma nova integração e novo papel social das favelas, relacionando diferentes formas de atuação, além de mostrar os impactos desta política pública na vida dos moradores dessas comunidades e o seu protagonismo na luta pelos seus direitos.

Desta maneira, no primeiro capítulo o mote será identificar eventuais pontos de divergência entre as premissas citadas na proposta de "integração da favela à cidade" contida na política de pacificação e uma leitura histórica e jurídica da emergência e do desenvolvimento das favelas com a finalidade de indagar: o Estado está ausente, total ou parcialmente, das favelas?. No segundo capítulo, analisaremos de que maneira a omissão do Estado gera informalidade nesses espaços, os seus desdobramentos e de que maneira ocorrem as interações entre poder público e comunidade. No terceiro capítulo, serão apresentadas algumas reflexões sobre o tipo de "integração" que é defendida por alguns autores, em especial Marcelo Neri, cujo objetivo é propor para esses territórios 
um "choque de ordem" associado a um "choque de mercado", além de abordar as novas formas de exploração desses espaços. Por fim, o quarto capítulo, de maneira breve, problematiza a eventual formação de uma "nova classe média" em virtude da exploração desses espaços e a sua aquisição de valor de mercado. 


\section{A Suposta Ausência do Estado nas Favelas}

Para iniciar esse ponto, vejamos as seguintes citações: (i) "na ausência de poder coercitivo legalmente constituído não há incentivos para os moradores respeitarem os códigos"; "a pacificação em andamento agora na cidade coloca uma oportunidade inédita de levar a legalidade e o Estado regulador (...) para as áreas informais;" "UPP Social: levando o Estado de volta"3; "as favelas cariocas constituem um caso paradoxal de 'ausência do Estado' e 'presença' não coordenada de centenas de projetos"4; "O eixo não é, e não deve ser, "levar os favelados ao cofre do Estado, mas muito mais 'levar o Estado às favelas'"; as favelas são áreas de habitação precária, sem presença do Estado e falta de regularização fundiária."

Por fim, destacamos o ponto de vista do Secretário Beltrame:

"As favelas se expandiram a olhos vistos, com barracos construídos sobre encostas e córregos, ante a apatia da população, da Justiça e dos governos municipal e estadual. $\mathrm{O}$ descaso teve como consequência a insegurança. $\mathrm{O}$ caos urbano fertiliza as ações criminosas. Foi desse vácuo legislativo e do poder público que se aproveitaram as quadrilhas para tomar conta da região." (grifo nosso) ${ }^{7}$

Traçando um breve histórico, urge problematizar alguns questionamentos oriundos das passagens supracitadas. Dessa forma, teriam as favelas sido formadas em razão da "apatia" do governo municipal, estadual e da Justiça? As favelas cariocas seriam resultado de um "vácuo" legislativo? O Estado regulador está ausente na história das favelas?

\footnotetext{
${ }^{2}$ GUIMARAES, S.F; CELIDONIO, M. Carências no acesso a serviços e informalidade nas favelas cariocas. In: Rio de Janeiro: Estado em transição, Rio de Janeiro: Editora FGV, 2012, p. 424.

${ }^{3}$ Banco Mundial, p. 38.

${ }^{4}$ HENRIQUES, R. RAMOS, S. UPPs Social: ações sociais para a consolidação da pacificação, p. 08.

${ }^{5}$ In . NERI, Marcelo [Coord]. UPP2 e a Economia da Rocinha e do Alemão: Do Choque de Ordem ao Progresso. FGV/CPS2011.

${ }^{6}$ NERI, P. 39

${ }^{7}$ In BELTRAME, José Mariano. Todo dia é segunda-feira. $1^{\text {a }}$ ed. Rio de Janeiro. Sextante. 2014. P. 77
} 
O termo "favela" provém da Guerra de Canudos, já que naquela região do sertão do estado da Bahia, existia um morro chamado Favella, porque era coberto por uma espécie de planta cujo nome era justamente "favela". As primeiras favelas que surgiram no cenário carioca datam do final do século XIX, por exemplo, o Morro da Providência, antigo Morro da Favella, que começou a ser ocupado com a tolerância do exército ${ }^{8}$. Os soldados que retornavam da guerra se estabeleceram no morro que se encontra atrás do prédio do antigo Ministério da Guerra, no Rio de Janeiro. A partir da segunda década do século $\mathrm{XX}$, esse termo passou a designar todas as habitações precárias do mesmo tipo espalhadas nos diversos morros da cidade.

O Morro da Favella, no entanto, já estava ocupado quando os soldados voltaram de Canudos em 1897. O prefeito Barata Ribeiro havia autorizado os habitantes de cortiços a utilizarem os restos da demolição dos mesmos, o que permitiu que alguns dentre eles se instalassem no morro, construindo seus próprios barracos com esses materiais. O surgimento das favelas, no primeiro momento, é uma consequência direta da política higienista contra os cortiços.

No caso do Morro de Santo Antônio, ocupado pelo menos desde 1893, um telegrama enviado no dia 13 de abril de 1897 por um agente municipal (Luiz de Freitas) ao diretor-geral de Obras e Viações demonstra que "os barracos foram construídos por ocasião da revolta armada, por ordem do governo (grifo nosso) e outros por conta própria". ${ }^{9}$. No ano de 1898 o Comandante Geral do $7^{\circ}$ Regimento, Affonso Pinto de Oliveira, posiciona- se junto ao Ministério da Guerra em favor da permanência dos moradores no Morro de Santo Antônio:

“esses casebres, porém, conquanto desprovidos de esgotos conservam- se em tal estado de asseio que me parece não causar perigo à saúde púbica (...) Attento ao grande número de praças casados neste batalhão e a deficiência de casas nas proximidades

\footnotetext{
8. A partir disso, o termo 'favela', que surgiu na Guerra de Canudos por se tratar de uma espécie de planta, com o mesmo nome até então empregado, que cobria os morros das cidades, passou a ser amplamente difundido.

${ }^{9}$ In GONÇALVES, Rafael Soares. Favelas do Rio de Janeiro: História e direito. $1^{\text {a }}$ ed. 2013. Rio de Janeiro. Pallas e Editora PUC-RJ. p.45.
} 
deste quartel (...) podem ser tolerados os ditos casebres e nesse sentido peço a vossa intervenção(...)"10.

Além desses, outros morros como a Quinta do Caju, a Mangueira e a Serra Morena datam do século XIX, com um povoamento do início do ano de 1881, nada provando que tenha resultado de uma ocupação ilegal, como destaca Lícia Valladares: "Tanto na Quinta do Caju quanto na Mangueira, os primeiros habitantes não parecem originários do mundo rural brasileiro, pois eram imigrantes portugueses, espanhóis e italianos, permitindo pressupor que o seu estabelecimento nessas áreas tenha sido autorizado". ${ }^{11}$

Adrelino Campos propõe uma teoria segundo a qual certas favelas se desenvolveram a partir da estrutura de antigos quilombos periurbanos, que se disseminaram em torno da capital durante a segunda metada do século XIX. Segundo o autor, é provável também que as ocupações dos morros tenham se iniciado logo após a Guerra do Paraguai, tendo em vista a falta de moradias populares para abrigar a massa de escravos libertos que se estabeleceram no Rio de Janeiro após a guerra.

Seguindo o itinerário histórico, a Lei no 2.087 , de 19 de janeiro de 1925 , foi a precursora de zoneamento do Rio de Janeiro, repartindo a cidade em quatro zonas: central, urbana, suburbana e rural. Se por um lado seguia a lógica de restringir a ocupação dos morros nas áreas centrais e nos bairros burgueses, por outro acrescentou novas dimensões ao objeto jurídico 'favela', como mostra o artigo 203 desse diploma legal: “Art.203.: A construção de casas de madeira só será permitida na quarta zona (rural) e nos morros situados fora da primeira zona (central), não o sendo, entretanto, nos morros de Santa Thereza, da Glória, da

\footnotetext{
${ }^{10}$ In GONÇALVES, Rafael Soares. Favelas do Rio de Janeiro: História e direito. $1^{\text {a }}$ ed. 2013. Rio de Janeiro. Pallas e Editora PUC-RJ. p.49.

${ }^{11}$ Do Prado Valladares, Lícia. "Passa-se uma Casa - Análise do Programa de Remoção de Favelas do Rio de Janeiro". Rio de Janeiro: Editora FGV, 2005. P.26.
} 
Viúva, do Pasmado e de Santa Maria"12. Em suma, a primeira lei de zoneamento do Rio de Janeiro acabou por autorizar a construção de barracos, desde que fora dos morros considerados valorizados.

Tal artigo, portanto, confirmava a tolerância em relação à favelização dos subúrbios, ao mesmo tempo que buscava coibir esse processo nas regiões centrais e burguesas. A política urbana, por meio da legislação, consistia, assim, em empurrar a expansão das favelas para os subúrbios e em limitar e ocultar aquelas que estavam situadas em bairros nobres. A intenção de tornar as favelas invisíveis é um elemento significativo que mostra o quanto elas eram definitivamente percebidas como fatores tão incômodos quanto problemáticos.

Já no período do Estado Novo, o então prefeito Pedro Ernesto, ciente da precariedade do mercado de trabalho do município e da crise de moradias, entendeu que o controle das massas iria necessariamente exigir a integração não apenas da classe operária residente nas favelas. Buscando estabelecer laços mais estreitos, concedeu subsídios às escolas de samba e abandonou todas as políticas públicas de remoção e reassentamento dos favelados. Sua administração alterou as relações políticas entre os poderes públicos e os favelados, utilizando o rádio, além de multiplicar as visitas às favelas e aos bairros de periferia. Em visita ao Morro de São Carlos, registra-se:

Preferiu a parte mais acidentada do morro, precisamente aquella onde nada se fez, até hoje, para melhorar as condições de vida de centenas de famílias que habitam os barracões (...) o interventor percorreu o morro, indo até as grimpas. Alli pode certificar-se de quanto necessita aquele bairro. Dando volta pela caixa d'água, o Dr. Pedro Ernesto desceu por verdadeiros precipícios e essa atitude do governador da cidade causou funda impressão à massa popular que o acompanhava na excursão ${ }^{13}$.

\footnotetext{
${ }^{12}$ Por sua vez, como indica Rafael Gonçalves, o Conselho Superior da Saúde Pública, em 8 de julho de 1886, propõe que a construção de barracos só fosse permitida "fora do centro da cidade, em pontos por onde passem os trens de ferro, ou bondes ou no cume dos morros de Santo Antônio, Castello, Senado, Paulo Mattos ou outros". Ou seja, não havia, do documento citado, a proposta de erradicação total, mas a ideia de uma espécie de "ordenação" das favelas no espaço urbano. In GONÇALVES, Rafael Soares. Favelas do Rio de Janeiro: História e direito. $1^{\text {a }}$ ed. 2013. Rio de Janeiro. Pallas e Editora PUC-RJ. p.86. ${ }^{13}$ GONÇALVES, Rafael Soares. Favelas do Rio de Janeiro: História e direito. 1 ${ }^{\mathrm{a}}$ ed. 2013. Rio de Janeiro. Pallas e Editora PUC-RJ. p.105.
} 
O então prefeito foi o primeiro a reconhecer a força política das favelas e admitir que elas poderiam constituir uma resposta concreta para o problema de moradia na cidade. Como relata Rafael Soares Gonçalves, o prefeito instalou serviços públicos nas favelas, abriu várias escolas públicas às margens das favelas e foi o primeiro a mandar construir uma escola no interior de uma delas. De certa maneira, o governo municipal confirmava o abandono da política de erradicação maciça dos barracos de madeira. ${ }^{14}$

No entanto, os tribunais ainda ordenaram alguns despejos, alguns deles por iniciativa de organismos públicos, como demolição, pelo chefe de polícia Dulcídio Gonçalves, da favela situada na Praia das Virtudes. Assim como, tal política não impediu algumas remoções no presente governo como os casos da Favela de São Carlos e o Morro do Capão. Segundo o autor, as favelas durante muito tempo conviveram com esse impasse e o jogo político no cenário carioca.

Se fizermos uma ponte, e agora nos situarmos já na era Vargas e analisarmos o Código de Obras de 1937, que segundo Rafael Soares Gonçalves, representou um recuo ao período de reconhecimento das favelas de Pedro Ernesto. Apesar das rigorosas imposições previstas pelo zoneamento, que afetava as construções de habitações nas regiões centrais, o código previa a possibilidade de conservar os moradores no local, desde que ali fossem construídos conjuntos habitacionais. O projeto dos parques proletários, lançado na década de 1940, demonstrou toda a ambiguidade da implementação das disposições do código.

Mais uma vez, o Código, apesar de objetivar a erradicação das favelas, autoriza as construções de madeira, desde que em áreas agrícolas, de subúrbio e nos morros situados fora das regiões centrais. Trata-se do artigo 292, que visava proteger os belos bairros da orla da favelização e privilegiar o interesse do mercado imobiliário dessas áreas. Portanto, novamente, o legislador se mostrava

\footnotetext{
${ }^{14}$ GONÇALVES, Rafael Soares. Favelas do Rio de Janeiro: História e direito. $1^{\mathrm{a}}$ ed. 2013. Rio de Janeiro. Pallas e Editora PUC-RJ. p.120.
} 
tolerante com a construção das habitações de madeira, desde que ocorressem em espaços definidos.

A construção de casas de madeira só será permitida em Z.A [Zona Rural e Agrícola] e nos morros situados fora da Z.C [Zona Comercial], Z.P [Zona Portuária], Z.I [Zona Industrial], Z.R.1 [Zona Residencial 1 - parte da Zona Sul atual e algumas ruas da Tijuca e Vila Isabel], não o sendo, entretanto, nos morros de Santa Teresa, do Pasmado, da Babilônia, e nas vertentes do lado do mar dos morros de São João, da Saudade, dos Cabritos e do Cantagalo ${ }^{15}$.

Essa contradição, somada à prática usual de não aplicação de normas urbanísticas, decorria provavelmente da lógica clientelista dominante. De certa maneira, o código privilegiou o interesse prioritário do mercado imobiliário. $\mathrm{O}$ poder público, incapaz de resolver de forma eficaz a crise habitacional, se via sistematicamente forçado a tolerar e até mesmo a estimular, os meios populares para que os habitantes pudessem dispor de sua moradia

Na década de 1950, o jornal Diário do Povo, precisamente no dia 17 de julho de 1951, registrou a participação de autoridades municipais na construção de casas e barracos:

“Apesar das disposições serem implacáveis, intransigentes, rígidas, segundo informou o Cel. Francisco Adolfo Rosas, diretor da Polícia Municipal, ontem, ao Diário do Povo, as autoridades municipais resolveram permitir que os favelados realizassem, nos barracos já existentes, melhoramentos, reparos, consertos, etc."16

No âmbito político, é certo que a estrutura política das favelas se inseriu nos mais variados canais institucionais. Rafael Gonçalves ainda cita o sociólogo Machado da Silva para demonstrar que essa relação entre as favelas e as disputas eleitorais promove a mesma a entrar nos canais administrativos seguindo a lógica da concessão de favores individuais ou coletivos, que de maneira geral procurava desmobilizar a população.

\footnotetext{
${ }^{15}$ GONÇALVES, Rafael Soares. Favelas do Rio de Janeiro: História e direito. $1^{\mathrm{a}}$ ed. 2013. Rio de Janeiro. Pallas e Editora PUC-RJ. p.118.

${ }^{16}$ GONÇALVES, Rafael Soares. Favelas do Rio de Janeiro: História e direito. $1^{\text {a }}$ ed. 2013. Rio de Janeiro. Pallas e Editora PUC-RJ. p.176.
} 
Na administração de Carlos Lacerda, apesar da posterior política de erradicação, o Rio de Janeiro teve a promulgação do Decreto Municipal $\mathrm{n}^{\circ}$ 13.304, de 28 de agosto de 1956, que previa uma participação popular mais marcante e encorajavam a criação de cooperativas de moradores nas favelas para colaborar com a urbanização dessas áreas, como ressalta o autor. Sob a responsabilidade de José Arthur Rios, coordenador de serviços sociais do governo, estabeleceu-se uma nova relação entre os poderes públicos e as associações de moradores. Implantou-se um vasto "programa de urbanização das favelas por meio de mutirões e de autoconstrução de casas, em que o governo fornecia o material e técnicos para orientar os trabalhos, e os favelados asseguravam a mão de obra"17.

A política urbana da administração de Carlos Lacerda deu uma guinada definitiva a partir de 1962, ano que inaugurou uma remoção em massa dos favelados, retomada e até intensificada pela ditadura militar a partir da segunda metade da década de 1960. A reação por parte dos moradores de favelas não demorou e por meio da FAFEG (Federação das Associações das Favelas do Estado da Guanabara), criticou-se a política de remoções e a tentativa de dominação das associações de moradores. Atuando de maneira combativa, o regime militar logo providenciou a prisão dos presidentes e diretores da FAFEG, além das associações de moradores, enfraquecendo a luta e removendo a Favela da Catacumba ${ }^{18}$.

No entanto, já no final da ditadura militar, atravessado por todo o tipo de resistências e desejando maior aprovação popular ${ }^{19}$, o governo federal retoma

\footnotetext{
${ }^{17}$ In GONÇALVES, Rafael Soares. Favelas do Rio de Janeiro: História e direito. $1^{\text {a }}$ ed. 2013. Rio de Janeiro. Pallas e Editora PUC-RJ. p.213.

${ }^{18}$ Apesar dos fracassos, os favelados conseguiram em alguns casos evitar a remoção, como cita Rafael Soares Gonçalves, "nos casos emblemáticos da Favela de Brás de Pina, que com o apoio de uma rede midiática, a associação de moradores e um pároco local impediu a destruição da favela", e começou a anunciar o prenúncio da grande derrota eleitoral de Carlos Lacerda.

${ }^{19}$ A política de erradicação continuava, mas a resistência também. Como é o caso da Favela do Vidigal, que no ano de 1977, foi alvo da prefeitura numa tentativa de erradicar a favela no interesse do mercado imobiliário, posto que constitui uma área de frente para o mar. Sob a alegação de perigo de desabamento das casas e proteção a vida dos favelados "o fracasso da tentativa tornou-se a referência histórica que
} 
programas de reconhecimento das favelas, em substituição das políticas de erradicação. No governo Negrão de Lima, foi criada a Companhia de Desenvolvimento de Comunidades (Codesco), que sustentava que as favelas não eram "totalmente irrecuperáveis, e que a sua urbanização era uma política econômica e socialmente mais viável que as remoções." 20 Assim, conclui-se que, mesmo no período mais autoritário com relação às políticas urbanas e de remoção, o poder público precisou colocar em prática políticas de urbanização e reconhecimento das favelas, demonstrando o quão falaciosa é a premissa de que o Estado esteve ausente desses territórios.

No período da redemocratização, logo após a promulgação da Constituição Federal, promulgou-se também uma nova Constituição para o Estado do Rio de Janeiro, estabelecendo que a política de desenvolvimento urbano deveria concentrar as ações na urbanização e regularização das áreas faveladas ${ }^{21}$.A legislação consolida as políticas de urbanização e de regularização fundiária das favelas, orientando a integração da favela ao bairro, a preservação da ocupação do solo, entre outras políticas de infraestrutura e regularização daqueles imóveis ${ }^{22}$.

Portanto, ao analisarmos os diferentes ciclos históricos, fica nítido que sempre houve uma relação entre o poder público e as favelas, inclusive com tentativas de ordenação através de regulações jurídicas. A premissa da "ausência

\footnotetext{
pôs fim às remoções, enquanto política pública". Por sua vez, o Banco Nacional da Habitação (BNH) ${ }^{19}$ passou a criar novos programas de habitação social, que incentivavam a construção gradual de habitação pelos próprios moradores. Programas para o financiamento de construção, conclusão, ampliação e financiamento de lotes urbanizados foram lançados pelo $\mathrm{BNH}$, além de introduzir a concessão de uso do solo, em conformidade com o disposto no Decreto-Lei Federal no 271, de 28 de fevereiro de 1967. Idem, ibidem. p. 263

${ }^{20}$ In GONÇALVES, Rafael Soares. Favelas do Rio de Janeiro: História e direito. $1^{\text {a }}$ ed. 2013. Rio de Janeiro. Pallas e Editora PUC-RJ. p.247.

${ }^{21}$ Neste ínterim, elaborou- se "uma nova lei orgânica da cidade do Rio de Janeiro, promulgada em 5 de abril de 1990". No que tange as favelas, o artigo 429 da lei orgânica, prevê que a política de desenvolvimento urbano deve concentrar-se na urbanização e regularização das áreas faveladas.

${ }^{22}$ Segundo o artigo 152, da Lei Complementar $n^{\circ}$ 16, de 4 de junho de 1992, as diretrizes são: 1) a integração da favela ao bairro; 2) a preservação da tipicidade da ocupação local do solo; e, 3) a previsão de implementação progressiva e gradual das obras de infraestrutura visando manter a complementariedade entre essas obras e os procedimentos de regularização fundiária.
} 
do Estado nas favelas" deve ser problematizada a partir desse contexto e identificar que tipo de nova relação entre poder público e favelas está se ensaiando a partir das UPP's. 


\section{A omissão do Estado gera informalidade nas favelas}

No capítulo anterior, vimos que, desde a emergência das primeiras favelas, houve uma relação destes territórios com o Estado, através de uma série de mecanismos: regulações jurídicas, intervenções públicas, presenças dos moradores em canais institucionais etc. A suposta "ausência do Estado nas favelas", portanto, é uma premissa que deve ser problematizada historicamente, através de um olhar que busca as relações específicas entre o poder público e a favela que foram traçadas pelo tempo.

A segunda premissa que será objeto de problematização é asserção de que, dessa suposta ausência do Estado, houve um domínio da informalidade nas áreas de favela. O decreto estadual 42.787/2011 do Rio de Janeiro, por exemplo, indica a ausência do Estado como causa do alto grau de informalidade presente nas favelas ${ }^{23}$, o que justificaria uma estratégia ativa com o objetivo de consolidar o controle estatal sobre tais territórios. O Instituto Brasileiro de Geografia e Estatística (IBGE), por exemplo, classifica as favelas, desde 1991, como aglomerados subnormais, tendo como principais características: “i) ocupação ilegal da terra e ii) padrões de urbanização e/ou precariedade de serviços essenciais." ${ }^{24}$

Em documento público lançado pela Secretaria de Assuntos Estratégicos sobre a integração da favela à cidade, subscrito por Ricardo Paes de Barros et ali, podemos ler: "A informalidade, a irregularidade, a precariedade, entretanto, sempre dificultaram e limitaram a capacidade do poder público em prestar esses serviços públicos"25. Para Sérgio Guimarães Ferreira e Maína Celidônio, ambos

\footnotetext{
${ }^{23}$ Segundo consta no artigo primeiro do decreto estadual 42.787 do Rio de Janeiro, as UPP's foram "criadas para a execução de ações especiais concernentes à pacificação e à preservação da ordem pública", visando contemplar áreas "compreendidas por comunidades pobres, com baixa institucionalidade e alto grau de informalidade,...".

24 In SAE. Integração entre favela e cidade, disponível em http://www.sae.gov.br/site/wpcontent/uploads/Integracao_entre favela-cidade.pdf Acesso em $28 \mathrm{de}$ julho de 2014.

${ }^{25}$ Idem, p. 3.
} 
com cargos de direção no Instituto Pereira Passos-RJ, a informalidade estaria relacionada à própria ilegalidade: "existe uma associação entre informalidade e ilegalidade. Nas favelas dominadas por grupos armados, os narcotraficantes ou milicianos exploram ilicitamente atividades que na cidade formal são exercidas pelo estado ou por suas concessionárias" ${ }^{26}$. Observação semelhante é realizada por Marcelo Neri: "a situação precária de moradia, combinada com insalubridade, a ausência de serviços sociais básicos e a superlotação acabam por criar um ambiente extremamente degradado"; "a dificuldade de acesso dentro das favelas, bem como a ausência do setor público e de segurança, criam o ambiente perfeito para a proliferação dessas atividades ilegais" 27 .

Contudo, outra vez atentando para a construção histórica das favelas desenvolvida pelos teóricos estudados, iremos notar que, na verdade, o poder público, não só não é ausente desses territórios, mas perpetua a informalidade como forma específica de relação política com as favelas. Segundo Rafael Gonçalves, o mote que orientou diversas políticas para as favelas cariocas é o "tolerar sem consolidar", isto é, realiza-se algumas ações de reconhecimento público, por muitas vezes como conquista dos moradores, mas evitando estabilizar e garantir a favela como espaço urbano legítimo. Segundo Rafael Soares Gonçalves:

"as favelas adquiriram progressivamente um status jurídico e político sui generis: toleradas, mas jamais consolidadas. Essa espécie de vazio jurídico constitui uma fronteira simbólica e institucional que define as favelas como territórios urbanos ao mesmo tempo marginais e estruturantes da cidade" 28 .

Assim, a perpetuação da informalidade aparece como uma estratégia política com razoável permanência durante os períodos históricos. Enquanto alguns encaravam e ainda vêem tais espaços como uma ofensa à propriedade e

\footnotetext{
${ }^{26}$ GUIMARAES, S.F; CELIDONIO, M. Carências no acesso a serviços e informalidade nas favelas cariocas. In: Rio de Janeiro: Estado em transição, Rio de Janeiro: Editora FGV, 2012, p. 435.

${ }^{27}$ Ibid., P. 07

${ }^{28}$ Ibid., p.122.
} 
a estrutura jurídica ${ }^{29}$, é preciso reconhecer que, na realidade, tal contexto de informalidade vem sendo promovido pelo próprio Estado ao longo da expansão das favelas.

A expansão das favelas constituiu um dos aspectos do acelerado processo de urbanização que afetou profundamente a cidade do Rio de Janeiro. Ainda que algumas leis tivessem reconhecido certos direitos sociais ao favelados, de forma geral, reforçou o status ilegal imposto pelo Código de Obras de 1937, colocando a favela como uma espécie de "outro lugar urbano" e justificou a indiferença dos poderes públicos para com o destino dessa categoria da população, que era cada vez mais numerosa.

De certa maneira, com a edição de decretos federais e lei municipais, buscou-se confirmar nitidamente a rejeição absoluta de qualquer iniciativa que visasse o reconhecimento oficial das construções. A ausência de um reconhecimento oficial dessa forma de ocupação do solo busca a caracterização de uma realidade específica. Como analisaremos, essa condição essencial é um dos argumentos mais significativos para suprimi-las do espaço urbano.

De acordo com Stephen Conn, o Estado adotou a precariedade fundiária das favelas como estratégia jurídica de perpetuação do status de ilegalidade e informalidade das mesmas ${ }^{30}$. Destaca-se, sobre o mesmo tema, a análise de Lícia Valladares, que ressalta a presença da política do favor, e não do direito, nesses territórios: "Estabelecia-se uma nítida relação de troca entre o voto e o favor obtido." 31 . Fazendo um paralelo, Alex Magalhães afirma que existe um "pacto" de subordinação que estabelece a dívida política como um fator essencial para a compreensão dos espaços de moradia das classes subalternas:

\footnotetext{
29،"Baseado na ilegalidade, no desrespeito à propriedade, a favela está em conflito com a estrutura jurídica da nação. ... não é justo que, de uma parte, se grave de tantos impostos e exigências a propriedade imobiliária, para, da outra, abandoná-la assim à violação e à posse clandestina. " - opinião publicada pelo jornalista Vinícius Lima na edição de 26 de Janeiro de 1952 do jornal O Globo.

${ }^{30}$ In CONN, Stephen, "The squatters' rights of favelados", p.68.

${ }^{31}$ Do Prado Valladares, Lícia. "Passa-se uma Casa - Análise do Programa de Remoção de Favelas do Rio de Janeiro". Rio de Janeiro. p.27.
} 
"os pactos entre o Estado e classes subalternas, no Brasil, estabelecem processos de troca que se retroalimentam continuamente, de forma que não se exaurem, não liberando o devedor de seus deveres ético-políticos para com o provedor, reproduzindo os vínculos que subordinam o polo em situação de inferioridade. Tratase de um pacto que é central naquilo que parece ser a origem das políticas de regularização dos espaços de moradia das classes subalternas." ${ }^{32}$ (grifo nosso)

Portanto, essa relação de troca de favores mantidas a margem de uma política de direitos enseja o não consolidamento das favelas como estratégia política, e não consequência de uma "omissão", além de afastar qualquer possibilidade real de transformação social e reivindicações mais concretas nessa seara. E nesse aspecto, podemos destacar alguns exemplos:

Já no início do século passado podemos claramente perceber, com a promulgação do Decreto $\mathrm{n}^{\circ} 2.636$, de 30 de setembro de 1914, a proposta de autorizar melhorias pontuais nas condições habitacionais das favelas, mas sempre adotando tais medidas em caráter provisório. Em razão da falta de meios (e do limitado interesse político) para a construção de habitações sociais, esse decreto inaugurou uma práxis política que passaria a ser usual nas favelas: "a outorga de concessões pontuais para reduzir as tensões sociais, conservandose, contudo, o caráter provisório e precário desses espaços urbanos. "33

Na década de 1950, diversos projetos de lei foram apresentados à Câmara de Vereadores ${ }^{34}$, mas que em geral tinham alcance limitado e insistiam em focar também apenas melhorias pontuais nas favelas. Ou seja, os melhoramentos não abriam espaço para a consolidação, mas para a manutenção da ilegalidade desses espaços: "tratava-se de manter a legitimidade simbólica da norma, permitindo, contudo, paradoxalmente, sua aplicação de forma arbitrária e seletiva." ${ }^{35}$ Dessa forma, fica nítido que foi criada uma tolerância condicionada à informalidade e

\footnotetext{
${ }^{32}$ In MAGALHÃES, Alex. Direito das Favelas. $1^{\text {a }}$ ed. Rio de Janeiro. Letra Capital Editora. p. 48.

${ }^{33}$ In GONÇALVES, Rafael Soares. Favelas do Rio de Janeiro: História e direito. $1^{\text {a }}$ ed. 2013. Rio de Janeiro. Pallas e Editora PUC-RJ. p.74.

${ }^{34}$ Ibid., p. 175 .

${ }^{35}$ Ibid., p. 175.
} 
fidelidade política por parte dos moradores, o que garantiria ao Estado o quadro propício para tolerâncias sempre revogáveis e eventuais remoções.

Outro exemplo, na mesma década, com repercussão nacional, trata-se da Lei no2.875- "Lei das Favelas", promulgada em 19 de setembro de 1956. Dentre as previsões dessa lei vale destacar os artigos $5^{\circ}$ e $6^{\circ}$, nos quais encontramos a probição de despejo de moradores de favelas durante o prazo de dois anos a contar da data da publicação da lei, bem como assegurar a permanência dos mesmos até que fossem beneficiados com casas populares. O que inicialmente parecia uma vitória de grande repercussão e apoio social, na verdade envolveu as favelas em mais precariedade, já que os moradores deveriam sair das favelas assim que as casas populares estivessem disponíveis. Com a ameaça de remoção sempre presente, os moradores não investiam em suas casas, já que a possivel iminência de saída daquele local não viabilizava um dispêndio financeiro de investimento nas construções diante da incerteza da permanência.

A Lei das Favelas também acabou por "impedir os moradores de serem formalmente locatários, contribuindo, paradoxalmente, para reforçar o status sui generis das favelas" - apesar de, na época, existirem várias decisões judiciais reconhecedo a relação locatícia ${ }^{36}$. Dessa maneira,o que acabou ocorrendo foi uma perpetuação do mercado imobiliário informal nas favelas, pela legislação criada. Não sendo possível praticar a compra e venda formalmente, com o tempo os moradores passaram a fazer uso de recibos e outros elementos formais que pudessem servir como algum tipo de prova ${ }^{37}$.

\footnotetext{
${ }^{36}$ In GONÇALVES, Rafael Soares. Favelas do Rio de Janeiro: História e direito. $1^{\text {a }}$ ed. 2013. Rio de Janeiro. Pallas e Editora PUC-RJ. p.194.

${ }^{37}$ É claro que tais documentos não constituiriam prova da propriedade do bem, mas pelo menos poderiam trazer legitimidade sobre a posse e servir de prova acerca do tempo decorrido para a declaração de usucapião. A informalidade surge e permanece como elemento de obstrução na luta pelo direito de propriedade dos moradores das favelas. Por exemplo, a concessão de direito real de uso por um número fixo de anos (99 anos) virou prática comum de alguns programas de titulação, mas a permissão de venda do imóvel permaneceu fora de questão. Tal estratégia foi predominantemente adotada pela prefeitura do Rio de Janeiro nas iniciativas de regularização feitas até $2008 .{ }^{37} \mathrm{O}$ instituto do usucapião vem sendo comumente utilizado como estratégia jurídica por parte dos moradores, mas o reconhecimento da propriedade por vezes se torna um sonho distante perante a longa duração do processo jurídico. Como resultado, poucos domicílios possuem escritura nas favelas cariocas. No Complexo do Alemão, onde
} 
Sendo assim, a Lei das Favelas, mais uma vez, não expandiu a tentativa de regularização fundiária na cidade, mas acabou por criar entraves na formalização das relações e perpetuar a informalidade ${ }^{38}$.

Já na década de 1970, o Código Tributário da Cidade (Decreto-Lei Estadual n. 06, de 15 de março de 1975), estabelecia a obrigação do registro municipal de todos os imóveis do município, mas excluia totalmente os imóveis situados em favelas, não conferindo às construções qualquer reconhecimento público. Na final da mesma década, apesar da existência de programas de urbanização e construção de casas, nenhum deste tocou na questão da legalidade fundiária, já que: "o sistema jurídico brasileiro privilegiava a proteção da propriedade privada, e as favelas constituíam uma espécie de exceção a regra"39.

Portanto, uma análise pontual de alguns períodos históricos, revela que a informalidade foi produzida, ao longo de décadas, através de estratégias jurídicas e políticas pelo próprio poder público do Rio de Janeiro. Por meio da política de favores, dos melhoramentos pontuais e do não reconhecimento da prática locatícia, notamos uma perpetuação de métodos que objetivam uma tolerância sem consolidação desses espaços como integrantes da cidade. Esse cenário busca ser transformado pelas novas propostas de integração da favela à cidade, mas nos resta, ainda, indagar de que forma.

temos o índice mais alto,encontramos apenas 13\%, enquanto que em Manguinhos, comunidade com menor número de domić́lios com escritura, encontramos somente 5\%. Sergio Guimarães Ferreira e Maína Celidonio, artigo "Carências no acesso a serviços e informalidade nas favelas cariocas: dialogando com as recentes pesquisas domiciliares e de estabelecimentos" presente no capítulo 15 do livro "Rio de Janeiro: um estado em transição", p.421.

${ }^{38}$ Consolidando o status ilegal das favelas, tal argumento sempre foi justificativa para afastar os investimentos públicos das favelas. De toda forma, surgiram leis que autorizavam e legitimavam juridicamente algumas intervenções públicas nas favelas como, por exemplo, a construção de praças públicas (Lei Municipal nº330, de 16 de julho de 1982), a instalação de iluminação pública (Lei Municipal nº380, de 8 de dezembro de 1982), e serviço de fornecimento de água (Decreto Estadual $\mathrm{n}^{\circ} 7.297$, de 25 de maio de 1984). GONÇALVES, Rafael Soares. Ibidem, p. 242. Sendo assim, nota-se a evidência da continuidade de uma política de tolerância da favela sem reconhecimento regular da mesma.

${ }^{39}$ Ibid, p. 270. 


\section{A regularização da informalidade como nova fronteira do mercado}

Durante a análise de trabalhos acadêmicos que pautam a política das UPP's e os desdobramentos que aconteceram após sua implementação, foi detectada uma grande preocupação com o aproveitamento econômico das áreas de favelas. Marcelo Neri escreve que:

"O pobre favelado é um pobre de recursos, não porque seu volume de riqueza é baixo, mas sim porque ele é morto, sem valor de mercado. (...) A informalidade e a violência acabam por gerar uma economia subterrânea, um excelente exemplo desse tipo de estrutura pode ser observado nas favelas das grandes metrópoles, como a Rocinha no Rio de Janeiro. Há uma perda de capital produtivo em um dos pontos mais nobres da cidade. ${ }^{40}$ (grifos nossos)

Nesse contexto, analisaremos que as UPP's se desenvolveram e permeiam um conjunto de estratégias que mantem relação direta com um projeto de cidade e de poder. Para melhor entendermos alguns dos métodos que levaram a criação das unidades de polícia pacificadora é necessário fazer uma breve digressão no âmbito da segurança pública e acontecimentos que se sucederam no Estado.

Nossa análise inicia-se durante o primeiro governo de César Maia. Durante muito tempo especulou-se que o estado de uma maneira geral já não tinha o mesmo prestígio desde o momento da transferência da capital para Brasília. Nesse interim, o então prefeito, iniciou um plano estratégico para o Rio de Janeiro, no qual buscava-se estabelecer um novo modelo de cidade, um padrão de referência. Devido a isso, iniciaram-se as tratativas e a corrida para a realização de grandes eventos, consolidando de vez a característica da cidade como um lugar ideal para acumulação de capital e turismo ${ }^{41}$.

\footnotetext{
${ }^{40}$ In NERI, Marcelo [Coord]; UPP2 e a Economia da Rocinha e do Alemão: Do Choque de Ordem ao Progresso; FGV/CPS2011.

${ }^{41}$ VIEIRA, Rafael Barros. Sobre o regime empresarial-militar de ocupação das favelas do Rio de Janeiro: uma análise crítica das UPPs. Revista Direito \& Práxis.Rio de Janeiro, Vol. 07, N. 15, 2016, p. $284-339$.
} 
Nessa esteira, durante o governo César Maia ocorreu a candidatura para sediar os Jogos Olímpicos de 2004. A prefeitura, ainda que derrotada, decidiu seguir a tendência empresarial, especialmente a local, e candidatou-se para os Jogos Pan-Americanos de 2007 como um teste para eventuais candidaturas que estariam por vir, como a Copa do Mundo e às Olimpíadas. Os grandes acontecimentos mantem uma relação extremamente importante no que tange a fusão das políticas públicas e a lógica do mercado de acúmulo de capital, ou seja, o padrão ideal de cidade é criado em torno da sua capacidade de segurança, o estabelecimento de padrões internacionais de oferta e consumo e sua capacidade de prevenção a eventuais conflitos.

Seguindo o itinerário histórico, notamos que o aumento dos gastos com "segurança pública" expande-se justamente em 2007, ano do Pan-Americano, o qual marcaria a primeira de uma série de mega-operações de guerra ao tráfico de drogas e a mesma que gerou uma ocupação policial-militar prolongada no Complexo do Alemão, que acabaria justamente no fim dos Jogos. Naquele momento, fica claro, que a demanda das classes dominantes por "segurança" passa a ser a pauta daqueles responsáveis por elaborar o plano de cidade ideal.

Com base nisso, implementou-se diversos projetos que desenbocariam na criação das Unidades de Polícia Pacificadora no ano de 2008. Dessa forma, as UPP's surgem não só em virtude da demanda, mas da necessidade de ação do grande capital. As UPP's recebem doações diretas de empresas privadas como Coca-Cola, CBF, Souza Cruz e Bradesco Seguros.

A título de exemplo, a Souza Cruz e a Coca-Cola financiaram a construção da sede da Ladeira dos Tabajaras e do Morro dos Cabritos, já a CBF financiou a instalação da UPP da Cidade de Deus ${ }^{42}$. Além disso, a Odebrecht realizou a terraplanagem para a construção das sedes da Fazendinha e Nova Brasília, ambas no Complexo do Alemão, e, coincidentemente, estações fixas

\footnotetext{
42 Ver: Folha de São Paulo 28/11/2010. Empresas ajudam a financiar pacificação. Disponível em: http://www1.folha.uol.com.br/fsp/cotidian/ff2811201040.htm.
} 
do Teleférico do Complexo, que é consorciado pela própria Odebrecht. No site ${ }^{43}$ da UPP, ainda encontramos empresas como Light, Firjan, Sebrae, Natura, Rio Top Tour, Associação Internacional Lions Club, Consulado Geral dos EUA, Ação Social da Música pelo Brasil, Viva Rio, LBV e outras definidas como parceiros em diversas atividades, como o "empreendedorismo".

As UPP's surgem como um elo do modelo empresarial urbano a ser proposto que tem o seu ápice nessa perspectiva dos grandes eventos. Busca-se a imagem de uma cidade segura e o efetivo controle da violência urbana. No âmbito das comunidades, muitos são os relatos e a formação da opinião de que as unidades de policia pacificadora visam dar uma satisfação pública e afirmar o controle do Estado nas comunidades, em virtude de todos os megaeventos e seus investimentos.

Nesse contexto, cumpre chamar atenção de que a implementação das UPP's, de certa maneira, acompanha o mapa da especulação imobiliária e da rota que viria a ser traçada pelos eventos. As primeiras unidades ocuparam a Zona Sul, Tijuca, Maracanã, Cidade de Deus e expandiram-se pela zona portuária, Centro e Zona Norte. A título de exemplo, dois dos maiores complexos de favelas da cidade foram ocupados nessa lógica. O Complexo do Alemão $^{44}$ foi ocupado em 2010 e ocupa as proximidades das vias de acesso da Zona Norte à Oeste, local que abrigaria as modalidades dos Jogos Olímpicos. O Complexo da Maré é passagem da via expressa responsável pela ligação do aeroporto internacional à Zona Sul da cidade e foi ocupado pelo exército. ${ }^{45}$

O papel das UPP's, desenvolvido pelas classes dominantes, seria o de terminar com o que chamam de 'cidade partida', o que ocorreria com uma

\footnotetext{
${ }^{43}$ http://www.upprj.com/index.php/parceiro.

${ }^{44}$ http:/passapalavra.info/2010/06/25791 - Tomazine, Eduardo.

${ }^{45}$ VIEIRA, Rafael Barros. Sobre o regime empresarial-militar de ocupação das favelas do Rio de Janeiro: uma análise crítica das UPPs. Revista Direito \& Práxis.Rio de Janeiro, Vol. 07, N. 15, 2016, p. $284-339$.
} 
integração entre favela e cidade. Segundo Alexandre Mendes ${ }^{46}$, essa proposta de "integração" é feita a partir da intensificação dos imperativos de produção e reprodução do capital. Segundo o autor, levando em consideração o texto "Rumo ao fim da Cidade Partida", a economista liberal e presidente do IPP, Eduarda La Rocque, tem como proposta o que ela denomina de PPP3 (Parceria PúblicoPrivada e com o Terceiro Setor), no qual ONG's seriam responsáveis pela implementação de políticas de viés empreendedor para articular na região de favelas uma mobilização para o capital.

É justamente nesse último elemento que a economista lança como fundamental o conceito de "Parceria Público-Privada e com o Terceiro Setor", representada pelo acrônimo "PPP3" (LA ROQUE, 2012, p. 197). A mobilização da "sociedade civil" e um novo arranjo entre público e privado devem caminhar juntos no caminho até a integração. ${ }^{47}$

Neste aspecto, a informalidade, que caracteriza estratégia de sobrevivência ao desemprego estrutural nessas áreas, é vista como um obstáculo a se transpor para a integração da favela ao modelo cidade-empresa. Assim como Marcelo Neri" ${ }^{48}$ La Rocque explicita a "necessidade" de transformação da informalidade em formalidade, eliminando riscos para o grande capital e com vistas a promover a ampliação de "novos mercados", ou seja, redução de risco e garantia de lucro. Esses fatores renderam às UPP's um comentário elogioso em um telegrama da Embaixada dos Estados Unidos para o Pentágono, como revelou o Wikileaks:

Além dos óbvios fatores de segurança envolvidos no programa de pacificação, há tambem interesses econômicos significativos em jogo, com muitos analistas estimando que a economia do Rio de Janeiro poderá crescer 38 bilhões de reais caso as favelas sejam reincorporadas à sociedade e aos mercados tradicionais. O programa de pacificação compartilha muitas características com a doutrina e estratégia de

\footnotetext{
${ }^{46}$ MENDES, Alexandre F. "Entre choques e finanças: a "pacificação" e a "integração" da favela à cidade no Rio de Janeiro”. Revista 'O Social em Questão' - Ano XVIII, no 031, 2014, p. 237-252.

${ }^{47}$ LA ROQUE, 2012, p. 197

${ }^{48}$ NERI, Marcelo [Coord]. UPP2 e a Economia da Rocinha e do Alemão: do Choque de Ordem ao Progresso. Rio de Janeiro: FGV/CPS, 2011.
} 
contra-insurgência dos EUA no Afeganistão e Iraque. O sucesso do programa dependerá em última instância não somente da coordenação eficaz e sustentada pela polícia e pelos governos estaduais e municipais, mas tambem da percepção dos moradores de favela da legitimidade do Estado ${ }^{49}$.

A dimensão de controle sobre a vida nas áreas de favela não só se dá pela regulação armada, mas mostra-se evidente ao querer formar os corpos úteis e dóceis que serão uma força eficiente de trabalho barata. Situação ilustrada, por exemplo, com a empresa Procter \& Gamble que se instalou na Cidade de Deus, um ano depois que a região foi ocupada pela polícia, com o governo municipal dando como incentivos a redução do IPTU e do ISS. A Philips no ano de 2011 fez consultas à Secretaria de Segurança sobre a instalação de uma UPP no Morro do Dendê, já que a empresa teria interesse de instalar uma fábrica na região ${ }^{50}$. O documento da Embaixada Americana termina da seguinte forma:

Se o programa ganhar mais corações e mentes nas favelas, e continuar a gozar de apoio genuíno do governador e do prefeito, reforçado pela iniciativa privada atraída pelas perspectivas de reintegração de cerca de um milhão de moradores de favela aos mercados tradicionais, esse programa poderá refazer a fábrica econômica e social do Rio de Janeiro. Esse consulado trabalhará em estreita colaboração com as autoridades estaduais competentes para facilitar o intercâmbio, seminários e parcerias institucionais para esse fim $^{51}$.

De certa maneira, a pacificação tambem relaciona-se a um movimento que deseja promover a aceitação dos termos da nova situação imposta, qual seja, pacificar aos trabalhadores residentes em favelas. Surge a pretensão de produzir uma força de trabalho disciplinada, ou seja, uma nova faceta da ocupação armada, que agora, busca espaço nas variadas formas de vida dessa população, mas que é enfrentada pela resistência dos próprios moradores.

\footnotetext{
${ }^{49} \mathrm{http} / / /$ wikileaks.ch/cable/2009/09/09RIODEJANEIRO329.html.

${ }^{50} \mathrm{http} / / / 0$ globo.globo.com/rio/apos-anos-de-esvaziamento-pacificacao-atrai-empresas-para-areasproximas-favelas-2911516\#

${ }^{51}$ http://wikileaks.ch/cable/2009/09/09RIODEJANEIRO329.html.
} 


\section{1 - A formação do conceito de UPP Social e a chegada de serviços}

Partindo da análise do decreto de criação das UPP's ${ }^{52}$, notamos que o seu objetivo principal é a criação de uma tropa especializada para a "execução de ações especiais concernentes à pacificação e a manutenção da ordem pública nas comunidades carentes" ${ }^{53}$. O decreto do Poder Executivo regula exclusivamente as atividades policiais em favelas, não ocorrendo qualquer formulação à UPP Social, que só seria criada em momento posterior como um braço de apoio ao foco principal do projeto que é a coercitividade das unidades na ocupação do espaço.

Implementada em 2011, a UPP Social quase chegou ao fim em 2013, mas em uma rápida manobra o Prefeito em conjunto com o então governador voltaram atrás da decisão ${ }^{54}$, já que ficaria muito claro o real objetivo da UPP, qual seja, ocupação militar dos territórios de pobreza, como parte de um projeto de cidade empresa e poder ${ }^{55}$. O conceito de UPP Social trabalha com o pressuposto de que a polícia é a porta de entrada para a chegada do social a essas comunidades, ou seja, o morador de favela só terá a capacidade de acesso a políticas sociais e a cidadania desde que ocorra a ocupação territorial-militar, criando uma cidadania policial para essas áreas.

A favela, via UPP, é tomada pelo estado como questão de segurança pública e policial. Ao declarar que uma fração da população e um local são perigosos, criando normas procedimentais para relacionar-se com eles em uma relação marcada pelo racismo frente a essas pessoas e pela verticalização das relações sociais, o poder público transforma " a responsabilidade pública em

\footnotetext{
${ }^{52}$ Decreto n. 41.650, de 21 de janeiro de 2009.

${ }^{53}$ Decreto n. 41.650, de 21 de janeiro de 2009. A regulamentação viria com o Decreto 42.787, de janeiro de 2011, quando já estavam instaladas 13 UPP's.

${ }^{54} \mathrm{http}$ ://oglobo.globo.com/rio/eduardo-paes-faz-acordo-com-sergio-cabral-upp-social-municipalizada2842792.

55 VIEIRA, Rafael Barros. Sobre o regime empresarial-militar de ocupação das favelas do Rio de Janeiro: uma análise crítica das UPPs. Revista Direito \& Práxis.Rio de Janeiro, Vol. 07, N. 15, 2016, p. $284-339$.
} 
tutela militarizada, exarcebando as divisões socioeconômicas existentes, fortalecendo atitudes discriminatórias e o preconceito" 56 como o caminho para lidar com essa parte da população da cidade.

Colocada como pré-requisito essencial, a polícia torna-se um regulador da vida social nas favelas nos mais diversos sentidos, criando uma espécie de prestação de contas à polícia. A partir de agora, é ela quem determina a realização de eventos, o horário e a altura do funcionamento do som, realiza revistas vexatórias em moradores e implementa toque de recolher em alguns locais ${ }^{57}$. O presidente da APAFUNK, Mc Leonardo, esclarece que:

A continuação do trabalho da UPP depois dos Jogos Olímpicos eu não sei qual vai ser, mas daqui para lá vai ser o policial tomando conta da luz, tomando conta da água, tomando conta do baile, tomando conta da festa de 15 anos, tomando conta da festa de todo mundo. A polícia decide tudo. UPP Social. O que seria isso? Unidade de Polícia Pacificadora Social? É a polícia que dá o Jiu-Jitsu. Para aprender Jiu-Jitsu? Polícia. A aula de capoeira? Polícia. Aí o SEBRAE quer entrar? Polícia. Aí não sei o quê? Polícia. Um dia desses eu vi o Secretário de Assistência Social e Direitos Humanos falando assim: "É que agora a gente vai tirar a identidade das pessoas, carteira de trabalho, vai vir um pessoal aí para colocar flúor, cortar cabelo. A primeira foi na Cidade de Deus". E a próxima? 'A próxima a gente vai ter que ver com o Secretário de Segurança'. Toda ação feita dentro das favelas para qualquer coisa, tudo passou a ser assunto da Secretaria de Segurança ${ }^{58}$.

Um grande debate se formou em torno dos bailes funk, que são uma das poucas opções de lazer dentro das favelas. Uma política promovida pelo Governo do Estado de constrangimento e proibição da realização de bailes funk em favelas ficou nítida, através da Resolução 013/2007, ao determinar que a polícia tem o direito de autorizar ou não a realização de bailes. Tal medida foi intensificada e implementada a partir de 2010 pela Secretaria de Segurança Pública. O estado passou a realizar a regulação dos bailes seja pelo poder discricionário da polícia, seja pela burocracia, que exige que haja um pedido

\footnotetext{
${ }^{56}$ PACHECO DE OLIVEIRA, João. "Pacificação e tutela militar na gestão de territórios e populações". Revista Mana, vol. 20, n 1, abril de 2014, p.145.

${ }^{57} \mathrm{http}: / /$ www.diplomatique.org.br/artigo.php?id=1353.

${ }^{58}$ Mc Leonardo durante o debate "Paz Armada". Semana Jurídica do CALC (Centro Acadêmico Luiz Carpenter - Direito UERJ) em 31/10/2011.
} 
com 20 dias de antecedência para realização de um baile funk, com a resposta das autoridades tendo de vir 8 dias antes.

Além disso, foram criadas outras determinações expressas em alguns locais, que exigem a instalação de câmeras e contratação de segurança para a sua realização, englobando festas de família, batizados e outros eventos familiares. Ainda que o governador Sérgio Cabral tenha revogado a resolução supracitada, depois de sofrer forte pressão pelas manifestações de 2013, a polícia continua regulando, na prática, a realização de bailes e eventos nas favelas, por via de procedimentos formais e informais da denominada fase de transição definida pelo chefe do executivo no comunicado de revogação.

Basicamente, a polícia passou a definir o que é cultura ou lazer, e o funk permanece no alvo de forma mais direta dessas proibições. Contudo, tem sido recorrente em áreas de UPP a realização de festas de classe média, com ingressos inacessíveis aos moradores dessas favelas ${ }^{59}$, que são obrigados a buscar opções de lazer em áreas distantes de onde moram. Dentre estas, festas de funk, mostrando que há um processo de marginalização e criminalização que são seletivos, já que no plano concreto ela incide sobre a população identificada com esse estilo de música a partir de critérios de raça e classe. Um morador do Santa Marta, afirma que:

Isso está deixando a comunidade muito revoltada. Porque a gente não tem condição de pagar cem reais numa festa. E, se a gente toca um funk, a polícia já vem com uma postura toda enviesada, enquanto as outras festas estão acontecendo sem nenhum problema $^{60}$.

Além da expansão das dinâmicas de regulação mercantil do cotidiano, a favela tornou-se um objeto de consumo, como nos casos de turismo de "safari", que são organizados por agências voltadas para estrangeiros interessados na

\footnotetext{
${ }^{59}$ http://www.cartacapital.com.br/sociedade/o-asfalto-invade-o-morro/.

60 http://noticias.uol.com.br/cotidiano/ultimas-noticias/2013/10/12/em-favelas-com-upp-baile-funkperde-a-vez-para-festas-de-classe-media.htm.
} 
'pobreza' e na 'adrenalina' de um local de conflito armado ${ }^{61}$. Este tipo de consumo associa-se a uma alteração da rotina desses espaços que passam a sofrer intervenções estéticas e negociais para a chegada de turistas e pessoas de classe média, como restaurantes, choperias e etc., que são inacessíveis para a grande maioria dos moradores, ocasionando um processo de aumento do custo de vida nesses locais.

Contudo, muitos moradores, através de relatos e entrevistas, retratam o fato de que pouco ou nada foi feito com relação as alterações sociais nas favelas com UPP. E o que geralmente foi feito ocorreu sem qualquer espécie de diálogo com as favelas e os seus moradores, em medidas que pouco surtiram efeito nas principais demandas desses lugares. Um exemplo notório foi a construção do Teleférico do Alemão, que mais tarde seria pauta em mais duas comunidades, Rocinha e Providência, o que gerou protestos e reivindicações por parte dos moradores. Em tempo, diversas comunidades, incluindo o Complexo, ainda sofrem com problemas básicos de saneamento, abastecimento de água, recolhimento irregular de lixo e a falta de estruturas básicas de saúde. Logo, desejariam ver essas demandas assistidas de maneira preferencial.

Caracterizada como uma extensão da cidadania, a chegada de "serviços", que só ocorreria através da ocupação militar, mostrou-se ilusória. Os serviços oferecidos estão muito mais vinculados a entrada de empresas privadas de telefonia, TV a cabo, agências bancárias, lojas de crediário e empresas prestadoras de serviços públicos. Segundo Maurício Campos ${ }^{62}$, logo depois da ocupação policial-militar, chegaram as favelas funcionários da SKY e empresas de telefonia interessados em vendas de pacotes. As principais demandas como

\footnotetext{
${ }^{61}$ VIEIRA, Rafael Barros. Sobre o regime empresarial-militar de ocupação das favelas do Rio de Janeiro: uma análise crítica das UPPs. Revista Direito \& Práxis.Rio de Janeiro, Vol. 07, N. 15, 2016, p. 284 339.

62 http://www.viomundo.com.br/denuncias/mauricio---campos---dos---santos---nao---ha---reforma--possivel---para---a---pm---que---atua---como---guarda---da---propriedade---de---escravos.html. Acesso em 22/08/2015.
} 
urbanização, saúde, moradia e educação não foram implementadas e não apresentam nenhuma perspectiva.

De certa maneira, a situação de muitos moradores piorou no que se refere a atuação da Light, empresa concessionária de energia elétrica, e à especulação imobiliária, ambas situações em virtude do processo de implementação das unidades de polícia pacificadora. Nos próximos dois itens abordaremos os respectivos temas enfrentando exemplos concretos que pautam a urgência da sua problematização.

\section{2 - A atuação da Light em favelas com UPP (Caso Chapéu-Mangueira)}

A Light há muito tempo tem fornecido seus serviços oficialmente e extraoficialmente às favelas do Rio de Janeiro. Com as implementações das UPP's a Light começou a regularizar os seus serviços e lidar com o problema histórico dos "gatos", as conhecidas ligações clandestinas de eletricidade no Rio de Janeiro. No entanto, cada vez mais, os moradores de favelas ocupadas pelas UPP's queixam-se dos aumentos das contas mensais, inexplicavelmente, a preços abusivos; falta de iluminação pública, bem como apagões e falhas no serviço ${ }^{63}$.

O problema mais grave ocorre em virtude do aumento do custo das contas. As reclamações de cobranças abusivas, falta de transparência na cobrança da tarifa e dificuldade de compreensão dos critérios de medição virou alvo de investigação por diversos grupos acadêmicos, sociais e mídia independente. O grupo Direitos em Movimento ${ }^{64}$, da PUC-Rio, elaborou um relatório sobre a atuação da Light no Morro Chapéu-Mangueira e chegou a conclusões estarrecedoras. O relatório baseou-se em um questionário no qual

\footnotetext{
${ }^{63}$ http://rioonwatch.org.br/?p=11037 - "Light emite contas contraditórias e serviço questionável em áreas de UPP".

64 Projeto Direitos em Movimento: Território e Comunidades. Relatório sobre o "Mutirão de atendimento e orientação jurídica aos moradores do Chapéu-Mangueira (Leme) em questões de direito à moradia e do consumidor de serviços de energia elétrica". Rio de Janeiro: PUC-Rio, 2013, p.9.
} 
fosse possível traçar um parâmetro de consumo dos moradores e com base nas contas de luz em período anterior a realização da pesquisa.

A análise dos parâmetros permitiu que os pesquisadores chegassem a relevantes conclusões. A primeira delas foi a constatação da realização de cobranças padronizadas, nos meses de outubro de 2012 a março de 2013, fixadas em $250 \mathrm{KW}$. Com efeito, ao longo desses meses, a maioria dos moradores participantes apresentou esta medição, em percentual nunca inferior a $60 \%$ e, em seu auge, no mês de janeiro de 2013, chegando a 78,13\% o índice de moradores com a medição fixada em $250 \mathrm{KW}$. Em virtude do perfil heterogêneo dos moradores, seria impossível que tantos consumissem exatamente a mesma quantidade por tanto tempo.

Se até esse presente momento foi observado a manutenção de um "teto de consumo" estabelecido em 250kW, a partir de abril de 2013 há uma mudança no quadro. O "teto" é extinto e pulverizado. Com efeito, este mês registrou 47,94\% dos moradores pesquisados consumindo 350kW. A partir daí, observouse um aumento de $100 \mathrm{~kW}$ no valor máximo consumindo, que chegaria a um máximo de $750 \mathrm{~kW}$ no mês de agosto de 2013. Note-se que esse quadro de aumento constante nas contas de luz se deu durante os meses de inverno que, historicamente, registram menores índices de consumo de energia elétrica na cidade do Rio de Janeiro.

O problema parece ter começado com a instalação dos novos medidores digitais, que substituíram o sistema analógico. O cliente não é capaz de ler o medidor e verificar o quanto ele está consumindo, portanto, deixando-o incapaz de controlar ou monitorar a quantidade que será cobrada. Em alguns casos, os medidores são ainda mantidos em caixas totalmente fechadas que impedem que o cliente tenha acesso a eles. Portanto, qualquer problema exige que um técnico da Light venha verificar o medidor. Ainda que os moradores façam reclamações frequentes à Light, o técnico solicitado nunca chega. 
Ademais, não foi constatado somente o aumento nas contas de luz, mas também uma precariedade dos serviços prestados. Com efeito nota-se no relatório reiteradas queixas sobretudo nos seguintes aspectos: (i) interrupção constante e injustificada do serviço; (ii) danos a eletrodomésticos e a bens de consumo em função das interrupções; (iii) exposição de fiação sem reparação pela concessionária, ainda que acionada pelos moradores; (iv) não envio, pela concessionária, das faturas de energia elétrica para pagamento; (v) ausência da medição de consumo e (vi) falta de atendimento, mesmo quando solicitado.

A sugestão de um aumento deliberado e premeditado nos custos da eletricidade toca em uma questão mais ampla, que é o aumento do custo de vida em favelas pacificadas. Para muitos, o aumento dos valores é parte de um processo de gentrificação e aumento do custo de vida. As novas particularidades na urbanização de áreas com UPP, afastam-se da alternativa real que durante muito tempo pautou as favelas que abrigavam as populações sub-remuneradas. Situação esta enfrentada por diversos moradores:

Morador aqui do morro quer pagar conta de luz, ele não quer viver do gato. Querem que o morador faça o que? Vai para a rua assaltar? Para pagar a conta de luz?. Como é que com um salário mínimo você vai pagar $\mathrm{R} \$ 300$ de conta de luz?. E se esse cara tem filho e se ele mora de aluguel? Vamos supor, aluguel mínimo aqui no morro é $\mathrm{R} \$ 500$, se ele paga $\mathrm{R} \$ 200$ de conta de luz já acabou, ele vai comer o que?

Portanto, ao analisarmos a atuação da Light em favelas pacificadas, notamos a estratégia pensada por Marcelo Neri ${ }^{65}$ que associa um choque de ordem a um choque de progresso, no qual deveria ocorrer uma transição escalonada e impositiva, na tentativa de "formalizar os serviços". Contudo, a atual sistemática vem acarretando abusos explícitos e recorrentes nas cobranças.

\section{3 - Especulação imobiliária e os desafios da Estradinha e Vila Autódromo}

\footnotetext{
65 NERI, Marcelo [Coord]. UPP2 e a Economia da Rocinha e do Alemão: do Choque de Ordem ao Progresso. Rio de Janeiro: FGV/CPS, 2011.
} 
Desenvolvida e implementada também em virtude dos "grandes eventos", a instalação das unidades de polícia pacificadora desencadeou um processo acelerado de aumento dos alugueis e dos custos de moradia nas favelas e no seu entorno. Se por um lado a especulação imobiliária, em todas as regiões que envolvem UPP's, atingiu índices de valorização que ultrapassam 100\% nos imóveis para compra e venda ${ }^{66}$, por outro, as favelas passaram a viver situação completamente oposta. Tal situação é exemplificada, especialmente, pelo encarecimento da moradia, das condições de existência e outras vertentes essenciais do cotidiano. No livro 'Da favela para as favelas', o rapper Fiell, morador do Santa Marta, exemplifica a situação:

Já se passaram mais de dois anos desde a implantação da UPP (Unidade de Polícia Pacificadora) no morro Santa Marta, Botafogo, Zona Sul do Rio de Janeiro. Já estamos em 2011, e ainda quase nada de melhoria coletiva chegou ao morro Santa Marta. Sim, medidas paliativas sim, isso chegou e irá chegar sempre. Será um desafio para todos os moradores permanecerem neste território de negócios para a especulação imobiliária. Vejo um outro morro Santa Marta, onde moram estudantes de classe média, estrangeiros. Onde há disputa para alugar um barraco de dois metros quadrados pela quantia de $\mathrm{R} \$ 350,00$. Vejo bar se transformando em república, vejo bares se adaptando à tendência de ser empreendedor. Até a chegada das Olimpíadas, em 2016, não sei se estaremos aqui no morro Santa Marta. Hoje, mais do que nunca, temos um custo de vida muito caro. A nossa conta de luz chega com valores aleatórios. No mês passado eu paguei $\mathrm{R} \$ 50,00$, sem ninguém ficar em casa, pois trabalhamos o dia todo fora. Nesse paguei $\mathrm{R} \$ 45$. Tenho conhecimento de que alguns moradores estão pagando $\mathrm{R} \$ 80, \mathrm{R} \$ 100$. Cadê a tarifa social? Sutilmente, estão higienizando a favela, sem que a totalidade dos moradores perceba. A mídia pulveriza a mente do trabalhador com o slogan da favela modelo e que temos que agradecer ao santo Sérgio Cabral, governador do Rio de Janeiro. O presidente Lula veio ao morro Santa Marta em setembro de 2010 e disse que temos que esquecer o nome favela, pois este já passou e é feio. Mas ninguém comenta a omissão com os moradores do pico do morro, pois lá não chegou absolutamente nada de urbanização. Toda essa transição beneficiou alguém: os enclaves fortificados dos ricos. Esses estão felizes da vida com o aumento dos seus imóveis, de $\mathrm{R} \$ 150$ mil para $\mathrm{R} \$ 300$ mil e $\mathrm{R} \$ 400$ mil etc. Hoje não podemos realizar o baile funk no morro, mas os blocos de fora do morro fazem seus eventos aqui e rola mais do que baile funk. A UPP também faz suas festas ${ }^{67}$.

\footnotetext{
$66 \mathrm{http} / / / \mathrm{www} . u p p r j . c o m /$ index.php/acontece/acontece-selecionado/proprietarios-de-imoveis-em-areascom-upp-estaeo-rindo-a-toa-com-a-valoriza/

${ }^{67}$ Repper Fiell. Da favela para as favelas: História e experiência do Repper Fiell. Rio de Janeiro: Malungo Comunicação e Editora, 2011, p. 61-63.
} 
A iminência dos grandes eventos aliada a especulação imobiliária, desenvolveu uma lógica de reprodução urbana, a partir da vertente de mercado, que passou a atingir especialmente os espaços das favelas. Num complexo de intervenções seletivas, que inicialmente poderiam incluir o PAC, as UPP's e o Choque de Ordem, por fim nos deparamos com as remoções que põe em movimento um projeto de cidade elitista e mercantilizado. Levando em consideração os aspectos abordados em tópicos anteriores, o poder público desvirtuando a demanda histórica da favela por urbanização, acaba por promover a expulsão da população pobre para áreas distantes dos centros, dando origem às remoções indiretas, decorrentes do aumento do custo de vida.

Aliando-se a esse processo, chegamos ao das remoções diretas. A cidade do Rio de Janeiro é marcada historicamente pela proximidade territorial das favelas com os bairros de classe média alta, contudo um novo desenho do mapa urbano surge, em virtude das remoções, sejam elas diretas ou indiretas, dessa população para as extremidades da cidade, como a Zona Oeste, afastando os trabalhadores das regiões centrais. Agora, além da especulação imobiliária, as remoções passam a ocorrer em funções de obras, que surgem em virtude do processo de preparação para os grandes eventos, ou por decretação de "risco" por parte da prefeitura. Este processo ocorre principalmente em favelas da Zona Sul.

Para melhor visualizarmos a situação, analisemos o caso da Estradinha ${ }^{68}$, favela localizada em Botafogo, zona sul da cidade. Levando em análise o estudo desenvolvido em artigo de monografia da aluna Carolina Pires. A grande valorização dos espaços urbanos impulsionou a retirada da população favelada das áreas nobres, devido aos lucros exorbitantes, que se tornaram objeto de cobiça por empresários e investidores. Contudo, na maioria das vezes, e no caso da Estradinha não foi diferente, os motivos alegados pelo poder público para a

\footnotetext{
${ }^{68}$ DOS SANTOS, Carolina Câmara Pires. A raça do gênero? As guerreiras da estradinha e a luta pelo direito à moradia adequada. 2013.
} 
execução dessa política consistiam em (i) danos ambientais; (ii) população situada em área de risco; (iii) adequação da cidade à estrutura exigida pelo Comitê Olímpico, como por exemplo, mobilidade urbana. Estes fatores somados a falta de informação sobre direito à moradia e a pressão do poder público contribuíram para a aceitação de remoção por alguns moradores, que acabavam aceitando qualquer proposta da Prefeitura.

Declarada como AEIS em 2000, para fins de regularização fundiária e urbanização, a localidade foi declarada como área de risco em 2010 por um relatório elaborado pela GEO-RIO, ainda que o órgão responsável não tenha feito nenhum tipo de vistoria no solo da comunidade. Tal fato nos faz problematizar a situação em busca da real situação. Assistidos pelo NUTH da Defensoria Pública do Estado do Rio de Janeiro, o engenheiro Maurício Campos, membro do corpo técnico, destacou a superficialidade do laudo apresentado pela GEO-RIO e em posterior vistoria na comunidade elaborou parecer capaz de enfrentar os pontos aduzidos pela prefeitura.

A partir dessa visita técnica, o engenheiro emitiu um parecer técnico, que além de demonstrar a fragilidade do laudo apresentado pelo poder público, apresenta soluções para o local, afastando a possibilidade de remoção da comunidade. Segundo este parecer, a Fundação GEO-Rio enviou ao NUTH um relatório de avaliação do risco geológico-técnico associado a escorregamentos para a comunidade Estradinha. Contudo, este relatório, reproduziu quase todo o conteúdo de relatório anterior, do mesmo ano, o qual fora destinado às comunidades do Laboriaux (Rocinha), Morro do Fogueteiro, Morro dos Prazeres e Complexo do Turano. Ou seja, não ocorreu um estudo detido a cada caso.

Dessa forma, o engenheiro Mauricio Campos buscou desconstruir os argumentos que vieram a embasar o laudo. No primeiro momento, demonstrou por meio de registro de aerofoto, que não havia expansão horizontal nos últimos dez anos, porem há um crescimento vertical das edificações, comum em todas as favelas, o que acaba com o argumento de que o crescimento da comunidade 
causa dano ambiental. Além disso, o relatório identificou diversas obras de contenção realizadas pelos moradores, tendo seus muros de contenção embasados em rochas, diminuindo bastante o risco de desabamentos.

No segundo momento, ao tratar da estabilidade do solo e os riscos de deslizamento, enquanto a prefeitura afirma que somente a remoção total será capaz de evitar tragédias, o perito encontra uma solução simples e barata, qual seja, o desmonte de blocos maiores de rocha ou com maior risco de rolagem e a execução de muros de contenção, preenchidos com as pedras da própria demolição, como medida que já foi feita em diversas localidades da cidade, por exemplo, o Morro Dois Irmãos. Nesse aspecto, o relatório da Prefeitura afirma ser inviável a recuperação da área, devido ao seu alto valor, estimado em $\mathrm{R} \$$ 1.950.000,00 (um milhão e novecentos e cinquenta mil reais), sem incluir a demolição e a retirada de entulhos.

No entanto, o parecer técnico discorda deste posicionamento, já que as demolições, a retirada de entulhos e as indenizações por residências, considerando que a Prefeitura negociou com alguns moradores valores acima de $\mathrm{R} \$ 100.000,00$ (cem mil reais), custariam um valor muito superior ao das obras de contenção propostas. Dessa forma, o relatório técnico do engenheiro Mauricio Campos concluiu que não existia qualquer fundamento técnico ou econômico na proposta de redação elaborada pelo poder público, com vistas a promover demolições desnecessárias que poderiam comprometer outras casas.

Situação equivalente à da comunidade Estradinha pode ser remontada com a favela do Vidigal no governo municipal de Marcos Tamoyo (1975-1979), que solicitou no dia 7 de outubro de 1977, que o estado de Rio de Janeiro efetuasse, por intermédio da Fundação Leão XIII, a erradicação daquela favela, para evitar riscos à vida dos favelados, em razão de uma pretensa erosão do solo. $\mathrm{O}$ prefeito, contudo, jamais conseguiu provar essas alegações. $\mathrm{O}$ discurso das autoridades municipais servia, na verdade, de fachada para uma importante operação imobiliária: a empresa Rio Towers projetava a construção de um hotel 
de luxo, desenhado pelo célebre arquiteto Oscar Niemeyer, na encosta de frente para o mar que era ocupada parcialmente pela favela ${ }^{69}$.

Portanto, através de vistoria técnica, foi possível concluir que a área da favela da Estradinha não se encontrava em risco e que os pontos de vulnerabilidade poderiam ser solucionados com simples obras de contenção. Assim, resta a certeza de que o verdadeiro motivo para a remoção da comunidade Estradinha é a extrema valorização do solo urbano, conhecida como especulação imobiliária.

Outro exemplo emblemático é o caso da comunidade Vila Autódromo, uma pequena favela localizada na borda do 'parque olímpico', que se viu no caminho das obras de preparação para os Jogos Olímpicos. Ao pretexto de abrir caminho para os Jogos e para o "legado olímpico", que privilegiaria as áreas mais carentes e a população mais pobre, iniciou-se uma das mais marcantes resistências a remoções dos últimos 6 anos.

A Rio 2016 trouxe enormes benefícios fiscais. Um estudo ${ }^{70}$ descobriu que as isenções fiscais olímpicas seriam cerca de quatro vezes maiores do que às da Copa do Mundo, onde incentivos fiscais foram de quase US\$250 milhões. Além disso, os bancos públicos assumiram riscos de negócios especulativos para respaldar projetos olímpicos e as autoridades locais usaram os Jogos para conceder terras públicas valiosas para empresários a preços mínimos.

Se os Jogos Olímpicos estavam focados sobre o setor imobiliário, o grande detalhe ficou por conta da Vila Olímpica, vizinha da Vila Autódromo, que foi construída pela Carvalho Hosken. Esta que será convertida em um complexo de habitação de luxo chamado 'Ilha Pura', que segundo Carlos Carvalho, fundador da empresa e doador de campanha do então prefeito, o nome na verdade se referia a uma 'ilha social', dizendo que ele queria criar "uma

\footnotetext{
${ }^{69}$ GONÇALVES, Rafael Soares. Favelas do Rio de Janeiro: História e direito. $1^{\text {a }}$ ed. 2013. Rio de Janeiro. Pallas e Editora PUC-RJ. p.263.

${ }^{70} \mathrm{http}: / /$ rioonwatch.org.br/?p=18274
} 
cidade de elite, de bom gosto... ela precisava ser moradia de nobre, não moradia de pobre". ${ }^{71}$

O mesmo prefeito Eduardo Paes, que na década de 1990, então subprefeito da Barra da Tijuca, alegando que o bairro estava com danos ambientais e estéticos, exigiu a demolição da comunidade da Vila Autódromo. Desde então, ele liderou o ataque para expulsar cada um dos seus últimos moradores. Diante desse cenário e reencontrando o então prefeito, restou a resistência, que em julho de 2015 gerou esforços policiais que acabariam em violentos.

As autoridades cortaram a água e a eletricidade da favela, além de promover "remoções relâmpago", baseada em decisões judiciais inéditas, contando com o respaldo da Guarda Municipal, que durante todo o tempo protegeu interesses do consórcio vencedor para a realização das obras, em detrimento dos interesses da população.

Por fim, embora tenha ocorrido uma grande remoção, algumas famílias venceram a disputa contra o projeto de cidade empresarial e solidificaram o seu direito à moradia na própria comunidade, ainda que a Prefeitura tenha tornado as condições de vida insuportáveis. Assim, encontramos mais um exemplo de remoção direta que possui como mote um projeto do empresariamento urbano.

\footnotetext{
${ }^{71} \mathrm{http} / / /$ rioonwatch.org.br/?p=18274
} 


\section{A Utopia da nova classe média}

Retomando o exposto anteriormente, é importante relembrar que o programa de implementação das Unidades de Polícia Pacificadora (UPPs) teve início em 2008, na cidade do Rio de Janeiro. Baseada na proposta de ocupação do espaço territorial, a UPP busca consolidar, em parte, o discurso de controle pelo Estado desses espaços que são controlados pelo tráfico de drogas. Por outro lado, propõe uma nova fase de regularização dos serviços públicos e geração de renda e/ou aproveitamento da renda lá existente como uma nova fronteira da integração das favelas.

Nesse contexto, notamos que o discurso governamental de integração para as favelas passa pela a análise do capitalismo contemporâneo e suas formas de acumulação. Segundo Alexandre Mendes $^{72}$, a população das favelas, classificada como a nova classe $\mathrm{C}$, "é o pedaço da sociedade civil a ser produzida e capturada pelas teias das finanças e do mercado, enquanto o Estado pratica as dores da pacificação e fomenta esse novo arranjo". De certa maneira, as UPP's surgem como o instrumento ideal para abrir caminho para essa nova "integração".

Segundo Giuseppe $\mathrm{Cocco}^{73}$, com a instalação das UPPs temos um processo de reorganização do controle territorial até então exercido pelos comandos do narcotráfico da venda de varejo de drogas. Na medida em que esses territórios estão se tornando o espaço de organização da acumulação em geral, ele não pode mais ser deixado sob o controle militar exercido pela economia criminal. Ocorre, então, novas formas de interação de capitalismo, que o autor denomina de capitalismo cognitivo.

\footnotetext{
${ }^{72}$ MENDES, Alexandre F. "Entre choques e finanças: a "pacificação" e a "integração" da favela à cidade no Rio de Janeiro". Revista 'O Social em Questão' - Ano XVIII, no 031, 2014, p. 248.

${ }^{73}$ Cocco, Giuseppe. O Complexo do Alemão e as mudanças na relação entre capitalismo mafioso e capitalismo "cognitivo". Entrevista concedida à IHU On-Line em 10/03/2011.
} 
Nesse aspecto, cabe fazer um breve parêntese sobre o momento citado para entendermos melhor essa reorganização. Na primeira década do novo século, em particular ao longo dos dois governos do presidente Lula, o Brasil teve taxas de crescimento do PIB moderadas. Entre 2003, ano que acabou a recessão mundial, e 2009, o PIB por habitante cresceu numa média de quase 3\%. Em 2010, cresceu 8\% se comparado ao primeiro trimestre de 2009, e 10,8\% com relação ao último trimestre de 2009. O crescimento moderado foi o contexto de mudanças estruturais que amplificaram de maneira qualitativa os efeitos do crescimento. ${ }^{74}$

Uma reorganização acelerada pelo fato de que as políticas sociais do governo Lula tornaram esses territórios, tradicionalmente entregue à exclusão, numa nova fronteira de expansão do capitalismo rumo à conquista daquelas camadas sociais definidas como "classe C". Ou seja, os pobres passaram a ter poder de compra e as favelas se tornaram territórios de consumo. Diante dos espaços gigantescos de moradia, as favelas se tornaram grandes jazidas de acumulação para o capitalismo cognitivo, que pode ser conceituado como a dimensão de uma produção que se torna serviço e que encontra na metrópole o espaço produtivo de uma circulação produtiva. ${ }^{75}$

Nessa esteira, outro fator de aceleração para essa reorganização ocorreu em virtude dos megaeventos da cidade. O Rio de Janeiro sediou, em 2011, as Olímpiadas Militares, em 2012 a cúpula do Rio+20, em 2014 uma parte da Copa do Mundo e, por fim, os Jogos Olímpicos Rio 2016. Tudo isso reconfigurou o espaço metropolitano e acelerou a corrida para uma acumulação que passa pelo controle do território.

A proposta de "integração da favela à cidade" não se limitou a uma produção específica da cidade do Rio de Janeiro, mas também foram elaboradas

\footnotetext{
${ }^{74}$ Cocco, Giuseppe. Korpobraz: Por uma política dos corpos. Rio de Janeiro: Mauad X, 2014.

${ }^{75}$ Cocco, Giuseppe. O Complexo do Alemão e as mudanças na relação entre capitalismo mafioso e capitalismo "cognitivo". Entrevista concedida à IHU On-Line em 10/03/2011.
} 
no âmbito da Presidência da República. A título de exemplo, destacamos um seminário realizado em 2012, intitulado "Integração da favela à cidade", no qual a Secretaria de Assuntos Estratégicos da Presidência da República elaborou um texto-base, cuja premissa é que as favelas estão "desintegradas" da cidade em razão do distanciamento com o "regular", a prestação de serviços públicos, os padrões "subnormais" urbanísticos, o controle do poder público e a legislação existente $^{76}$.

De certa maneira, a favela é um campo de atuação para o Estado, que deve assumir a agenda da formalização, do poder de polícia e do controle público. E no texto encontramos a seguinte afirmação: "a formalização das atividades nessas comunidades deverá elevar, por sua vez, os custos para empreendedores e usuários de serviços públicos (BARROS et al, 2012, grifo nosso) ". Neste aspecto, a toda essa efetivação da atuação estatal passa por uma questão do aumento de custos de vida. Tal premissa é colocada expressamente pelos autores do texto-base, e, de certa forma, encarada como uma consequência natural, como um efeito normal e previsível. A formalização, operada por intervenções públicas, "deverá" elevar os custos para os moradores e comerciantes da favela.

A análise de todo esse processo de aumentos de custo de vida e integração desses espaços passa a ser muito debatido e pensado devido a pluralidade de agentes que por ventura serão prejudicados. Nesse aspecto, os autores assumem o caráter unilateral da medida, admitindo que na maioria das vezes a comunidade não é consultada sobre seu interesse na integração. Os autores afirmam que como essa hipótese caracterizaria uma mudança imposta, que não necessariamente foi demandada seria natural o oferecimento de um período para ajustarem-se à nova ordem.

\footnotetext{
${ }^{76}$ MENDES, Alexandre F. "Entre choques e finanças: a "pacificação" e a "integração" da favela à cidade no Rio de Janeiro”. Revista 'O Social em Questão' - Ano XVIII, n’ 031, 2014, p. 241.
} 
Dessa forma, a Secretaria de Assuntos Estratégicos propõe o que eles denominam de uma "transição escalonada" na qual será oferecido para a comunidade um período de incentivos para "o ajuste à nova ordem". Ou seja, cientes de que tais medidas pudessem gerar resistência dos habitantes de favelas ao aumento do custo de vida e dos custos nas atividades geradores de renda, os autores propõem uma integração unilateral, sem participação. Em breve resumo, a integração unilateral é operada por uma estratégia de imposição sutil e progressiva de uma ordem na qual a participação democrática e comunitária é naturalmente afastada. Neste aspecto, registre-se:

Integração unilateral - Uma questão a ser enfrentada na integração é precisamente a importância e a adequação de legislação que seja específica para as comunidades, assim como a necessidade de um período de transição para a formalização. Há dois argumentos nesse sentido: $\left(1^{\circ}\right)$ A regularização representa uma profunda mudança nas regras de funcionamento da comunidade. Isso significa mudanças de hábitos e com custos de magnitude significativa na maioria das vezes. Uma das formas de mitigar alguns desses custos e tornar a mudança de hábitos viável é a opção por uma transição escalonada e programada. $\left(2^{\circ}\right)$ A natureza unilateral da integração. Normalmente, a comunidade não é consultada sobre seu interesse na integração. Dessa maneira, presume-se que o interesse coletivo encontra-se acima dos interesses locais. Como uma mudança imposta, não necessariamente demandada, é natural que se ofereça um período e incentivos para ajuste à nova ordem.

Ou seja, a favela precisa ser anexada à cidade e pautar uma dinâmica de serviços, todos privatizados, através de um poder público que possa garantir tal mudança, que será baseada na imposição e unilateralidade. A integração unilateral busca suavizar os custos e dissabores da chamada "formalização". Nesse caso, negocia-se a democracia em prol de um genérico "interesse coletivo", na mesma medida que o possível sufocamento dos moradores é assumido como uma consequência natural dessa nova etapa de "valorização" das favelas.

A lógica da integração pelo mercado é abordada pelo economista Marcelo Neri no texto denominado UPP2 e a Economia da Rocinha e do Alemão: Do Choque de Ordem ao de Progresso (2011)15, denominando o processo como um "choque de formalização", o autor chega a algumas conclusões. Segundo 
ele, a formalização não levaria somente ao aumento da arrecadação tributária, mas, principalmente, à abertura das favelas ao mercado. A arrecadação de IPTU e dos impostos relacionados às atividades comerciais e de serviço seriam importantes, mas, o fundamental seria, a partir da função primordial do Estado em fornecer segurança e o império da Lei, "completar a operação dos mercados":

O eixo não é, e não deve ser, levar os favelados ao (cofres do) Estado, mas muito mais levar o Estado às favelas e com isso pela função talvez mais primitiva do Estado de prover segurança e o império da lei e com isso (sic) completar a operação dos mercados. É preciso ir além e dar o mercado as comunidades, completando o movimento dos últimos anos quando houve queda da desigualdade entre favela e asfalto, demos os pobres aos mercados (consumidores). Um choque de crédito materializado pela oferta de microcrédito de qualidade, já que o crédito produtivo popular é fundamental para dar vazão aos espíritos empreendedores das comunidades de baixa renda que serão incensados com a revolução na segurança.

Segundo Marcelo Neri, o choque de ordem das unidades de polícia pacificadora cria um terreno expansivo para o progresso. Ou seja, "o choque de ordem das UPPs cria terreno fértil para o desenvolvimento dos mercados consumidores na base da pirâmide" (NERI, 2011, p. 39). Segundo Neri, uma "nova classe média" emergirá do reconhecimento do direito de propriedade nesses territórios e que deve ser acompanhado de políticas públicas e regulatórias. Além disso, as UPPs "abrem o mercado desta classe média emergente às empresas de fora que ainda tem o interesse de colocar suas marcas nas favelas por merchandising" (NERI, 2011 p. 40). O choque de progresso seria o "crescimento vertical" contínuo das favelas no sentido de expandir os limites colocados aos mercados e ao Estado ${ }^{77}$.

Em outra obra literária, intitulado O lado brilhante dos pobres (2010), Marcelo Neri e sua equipe traçam uma ampla análise estatística para demonstrar a centralidade da chamada "Classe C" no Brasil. A "nova classe média" aqui é

\footnotetext{
${ }^{77}$ MENDES, Alexandre F. "Entre choques e finanças: a "pacificação" e a "integração" da favela à cidade no Rio de Janeiro”. Revista 'O Social em Questão' - Ano XVIII, n’ 031, 2014, p. 243.
} 
definida a partir de Thomas Friedman, que no livro $O$ mundo é plano, afirma que a classe média é "aquela que tem um plano bem definido de ascensão social para o futuro" (NERI, 2010, p. 26). A definição não é feita ao acaso, o esforço do livro é mostrar que o governo brasileiro, nas pegadas na nova classe média, realiza um caminho de crescimento gradual que o coloca, de forma relativamente segura, imune à crise global que irrompeu em 2008.

A lógica de uma atuação dupla de choque de ordem, que deveria desenvolver um "Choque de Progresso" seria extremamente compatível com as análises desenvolvidas sobre a economia brasileira. Busca-se alinhar uma formação com a suposta nova classe média, o mercado e o Estado. $\mathrm{O}$ alinhamento proposto está baseado numa expansão de crescimento do capitalismo que se propõe pela anexação das favelas e toda a sua capacidade produtiva à disposição do mercado, além de buscar uma afirmação do estado no âmbito de regulação da sociedade, como um garantidor da propriedade e realizador das políticas públicas em pauta de igualdade para toda a cidade.

Dessa forma, os discursos apresentados como proposta de integração desses espaços da cidade, especialmente os idealizados pela lógica do capital, definem um processo baseado em novas formas de interação entre público e privado. A proposta de formalização aqui pensada é assumida como processo unilateral e subsidiada por mecanismos de transição que teriam como finalidade aliviar o aumento do custo de vida dos moradores, que basicamente são excluídos de eventuais construções dos espaços que residem. Além disso, propõem-se um choque de ordem e de formalização para a abertura da favela aos mercados e ao merchandising, conduzidos por um novo protagonismo da Classe $\mathrm{C}$, que deseja gradualmente consumir e ascender socialmente. Como conceitua Giuseppe Cocco, a nova classe média do Brasil constitui para o mercado uma nova jazida de acumulação, tal como um novo eldorado para uma dupla acumulação primitiva: aquela típica do subdesenvolvimento e aquela "inovadora" do capitalismo cognitivo. Na prática, as favelas do Rio de Janeiro buscam resistir 
contra o discurso do "interesse geral" para defender sua capacidade de produzir em comum seus espaços e suas formas de vida. 


\section{Considerações Finais}

A partir dos eixos de pesquisa percorridos, o presente trabalho buscou problematizar duas premissas que surgem e servem de base para a proposta de “integração da favela à cidade" veiculado pela política de pacificação (UPPs), decorrentes da noção de que as favelas surgem como resultado de uma omissão do Estado. Percebemos, através do itinerário histórico, que desde a construção dos primeiro barracos o poder público e a regulação jurídica estiveram presentes. Além disso, notamos que a informalidade das favelas é construída também pelo poder público, a partir da ideia de "tolerar sem consolidar", isto é, de conferir um caráter provisório evitando qualquer tipo de estabilização e garantia das favelas.

No aspecto de formação das UPP's notamos que a política de pacificação pautou-se em duas vertentes. Inicialmente, as UPP's caracterizaram um elo fundamental do modelo empresarial urbano a ser proposto que tem o seu ápice nessa perspectiva dos grandes eventos, buscando a imagem de uma cidade segura e o efetivo controle da violência urbana. Por outro lado, as unidades de polícia pacificadora atuam como ator principal do processo de gentrificação dos espaços urbanos, principalmente nas favelas da zona sul e outros espaços que se encontram no caminho da valorização imobiliária, como restou demonstrado nos casos da Estradinha e Vila Autódromo.

No tocante à proposta de "integração" apresentada por acadêmicos e documentos governamentais, abordamos alguns discursos que classificam as favelas como uma nova perspectiva de mercado, buscando um maior aproveitamento econômico possível, ainda que problemas estruturais básicos de saneamento não tenham sido sanados, propondo uma "formalização" impositiva e escalonada desses espaços. Esta consiste basicamente numa expansão da cobrança de serviços, atividades e produtos via mercado, que abrem um amplo espaço para cobranças indevidas e arbitrárias: choque de ordem e de mercado. 
Por fim, analisamos o que foi caracterizado como o fenômeno da nova Classe "C", ou nova classe média do Brasil, que surge como a tentativa de exploração dos pobres que passaram a ter poder de compra tornando as favelas territórios de consumo. Diante dos espaços gigantescos de moradia, as favelas se tornaram grandes jazidas de acumulação para o capitalismo constituindo para o mercado uma nova jazida de acumulação. Contudo, as favelas do Rio de Janeiro buscam resistir contra o discurso do "interesse geral" para defender sua capacidade de produzir em comum seus espaços e suas formas de vida. 


\section{Referências bibliográficas}

BARROS, Ricardo et al. Integração da favela à cidade. Brasília: Presidência da República - Secretaria de Assuntos Estratégicos, maio de 2012.

BELTRAME, José Mariano. Todo dia é segunda-feira. $1^{\text {a }}$ ed. Rio de Janeiro. Sextante. 2014.

BORDA.SILVA. SANTOS.POLÍTICA DE PACIFICAÇÃO DAS FAVELAS (UPP_S) - FUNDAMENTOS JURÍDICO- POLÍTICOS E SUAS CRÍTICAS.

Cocco, Giuseppe. KorpoBraz: Por uma política dos corpos. Rio de Janeiro: Mauad X, 2014.

Cocco, Giuseppe. O Complexo do Alemão e as mudanças na relação entre capitalismo mafioso e capitalismo "cognitivo". Entrevista concedida à IHU OnLine em 10/03/2011.

CONN, Stephen. "The squatters' rights of favelados".

Decreto n. 41.650, de 21 de janeiro de 2009. A regulamentação viria com o Decreto 42.787, de janeiro de 2011, quando já estavam instaladas 13 UPP's.

DOS SANTOS, Carolina Câmara Pires. A raça do gênero? As guerreiras da estradinha e a luta pelo direito à moradia adequada. Monografia apresentada $\mathrm{e}$ publicada pela PUC-Rio, 2013.

Fala de Mc Leonardo durante o debate "Paz Armada". Semana Jurídica do CALC (Centro Acadêmico Luiz Carpenter - Direito UERJ)

Disponível em: http://www.youtube.com/wacth?v=hJlllf6hHS-k

Folha de São Paulo 28/11/2010. Empresas ajudam a financiar pacificação.

Disponível em: http://www1.folha.uol.com.br/fsp/cotidian/ff2811201040.htm. Acesso em 17/11/2016

GUIMARAES, S.F; CELIDONIO, M. Carências no acesso a serviços e informalidade nas favelas cariocas. In: Rio de Janeiro: Estado em transição, Rio de Janeiro: Editora FGV, 2012. 
GONÇALVES, Rafael Soares. Favelas do Rio de Janeiro: História e direito. $1^{\mathrm{a}}$ ed. 2013. Rio de Janeiro. Pallas e Editora PUC-RJ.

HENRIQUES, R. RAMOS, S. UPPs Social: ações sociais para a consolidação da pacificação.

http://noticias.uol.com.br/cotidiano/ultimas-noticias/2013/10/12/em-favelascom-upp-baile-funk-perde-a-vez-para-festas-de-classe-media.htm. Acesso em: 20/08/2016

http://www.upprj.com/index.php/acontece/acontece-selecionado/proprietariosde-imoveis-em-areas-com-upp-estaeo-rindo-a-toa-com-a-valoriza/. Acesso em $17 / 11 / 2016$

http://rioonwatch.org.br/?p=11037 - "Light emite contas contraditórias e serviço questionável em áreas de UPP”. Acesso em: 17/11/2016

http://www.upprj.com/index.php/parceiro. Acesso em: 17/11/2016

http://www.sae.gov.br/site/wpcontent/uploads/Integracao_entre favelacidade.pdf. Acesso em: 28/07/2014

http://www.diplomatique.org.br/artigo.php?id=1353. Acesso em 17/11/2016.

http://wikileaks.ch/cable/2009/09/09RIODEJANEIRO329.html.

Acesso em: 17/11/2016

http://oglobo.globo.com/rio/eduardo-paes-faz-acordo-com-sergio-cabral-uppsocial-municipalizada-2842792.

MAGAlHÃES, Alex. Direito das Favelas. $1^{\mathrm{a}}$ ed. Rio de Janeiro. Letra Capital Editora, 2013.

MENDES, Alexandre F. "Entre choques e finanças: a 'pacificação' E a 'integração' Da favela à cidade no Rio de Janeiro". Revista 'O Social em Questão' - Ano XVIII, n³1, 2014, p.237---252.

NERI, Marcelo [Coord]. UPP2 e a Economia da Rocinha e do Alemão: do 
Choque de Ordem ao Progresso. Rio de Janeiro: FGV/CPS, 2011.

PACHECO DE OLIVEIRA, João. "Pacificação e tutela militar na gestão de territórios e populações". Revista Mana, vol. 20, n 1, abril de 2014, p.145.

PUC-Rio (Núcleo de Estudos Constitucionais - NEC). Mutirão de atendimento e orientação jurídica aos moradores do Chapéu-Mangueira (Leme) em questões de direito à moradia e do consumidor de serviços de energia elétrica. Relatório técnico de pesquisa, 2013.

Repper Fiell. Da favela para as favelas: História e experiência do Repper Fiell. Rio de Janeiro: Malungo Comunicação e Editora, 2011.

SILVA, Gerardo. Refavela: notas sobre a definição de favela. In: Lugar Comum. Rio de Janeiro: E-papers, n. 39, pps 37-43.

VALLADARES, Lícia do Prado. Passa-se uma Casa: Análise do Programa de Remoção de Favelas do Rio de Janeiro. Rio de Janeiro: Editora FGV, 2005.

VIEIRA, Rafael Barros. Sobre o regime empresarial-militar de ocupação das favelas do Rio de Janeiro: uma análise crítica das UPPs. Revista Direito \& Práxis.Rio de Janeiro, Vol. 07, N. 15, 2016. 
